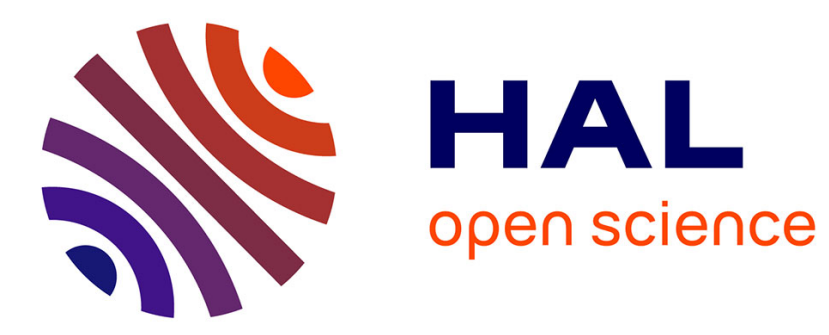

\title{
Human-shaped landscape history in NE Greece. A palaeoenvironmental perspective
}

Arthur Glais, Laurent Lespez, Boris Vannière, Jose Antonio Lopez-Saez

\section{To cite this version:}

Arthur Glais, Laurent Lespez, Boris Vannière, Jose Antonio Lopez-Saez. Human-shaped landscape history in NE Greece. A palaeoenvironmental perspective. Journal of Archaeological Science: Reports, 2017, 15, pp.405 - 422. 10.1016/j.jasrep.2017.06.017 . hal-01731091

\section{HAL Id: hal-01731091 \\ https://hal.science/hal-01731091}

Submitted on 19 Mar 2018

HAL is a multi-disciplinary open access archive for the deposit and dissemination of scientific research documents, whether they are published or not. The documents may come from teaching and research institutions in France or abroad, or from public or private research centers.
L'archive ouverte pluridisciplinaire $\mathbf{H A L}$, est destinée au dépôt et à la diffusion de documents scientifiques de niveau recherche, publiés ou non, émanant des établissements d'enseignement et de recherche français ou étrangers, des laboratoires publics ou privés. 


\title{
Human-shaped landscape history in NE Greece. A palaeoenvironmental perspective
}

\author{
Arthur Glais ${ }^{1}$, Laurent Lespez ${ }^{2}$, Boris Vannière ${ }^{3}$, José Antonio López-Sáez ${ }^{4}$ \\ ABSTRACT
}

Following palaeobotanical, sedimentological and archaeological research recently conducted on and around the tell of Dikili Tash (Eastern Macedonia, Greece), we present continuous palaeoenvironmental data on this multi-period site. This study combines pollen, non-pollen palynomorphs (NPPs), macro-charcoal and sedimentological analyses that are compared with archaeological data from the Middle Neolithic to Antiquity period. It provides an overview of the local environment near the former Tenaghi-Philippon marsh and a comprehensive view of human impact on vegetation cover in lowlands. As early as ca. 4550 cal BC, an initial phase of change in vegetation cover, has been recorded. This period, in the Eastern Mediterranean region, is one of intensifying human activities and social interactions into the Balkan region, which resulting in the foundation and transformation of early Late Neolithic societies. Although the palynological record does not show the crops species grown, the intensive clearance resulted in the increase of open herbaceous landscapes with anthropogenic indicators. This, as well as the increase of macro-charcoal values strongly supports a more or less continuously shaping of the landscape by human induced fires. New tree species that also became established at this time include Olea and Castanea. . The presence of three main formations can be argued from the Early Neolithic to Antiquity: (1) riparian vegetation, (2) oak woodlands and (3) open vegetation in the form of wooded grasslands. Beyond the responses to climate changes, the vegetation composition reflects a regionally diversified land management system as indicated by a greater diversity in cultivated or harvested plants. The study reveals two phases of decline in land use directly on the edge of the marsh, although indicators of anthropogenic disturbance of the vegetation never entirely disappear during these periods between 3900-3300 cal BC at the transition from the Late Neolithic (LNII) to the Bronze Age and from 1650-800 cal BC when we observe a reorganization of the settlement on the higher slopes. In contrast, four periods are characterized by an increase in land use extension and intensification: Late Neolithic (4500-3900 cal BC); Early to Middle Bronze Age (3000-1600 cal BC), the Iron Age (1000-800 cal BC) and Antiquity during the Macedonian (ca. 357-148 cal BC) and Roman periods (148 cal BC-cal AD 395).

Keywords: Neolithic; Bronze Age; human impact; land use; palynology; macro-charcoal; Balkans; Northeast Greece.

\footnotetext{
${ }^{1}$ University of Caen Normandy, LETG-CAEN CNRS-UMR 6554, France, arthur.glais@unicaen.fr

2 Laboratory of Physical Geography (LGP) CNRS-UMR 8591, University of Paris-East Créteil, France, laurent.lespez@u-pec.fr

${ }^{3}$ CHRONO-ENVIRONNEMENT UMR 6249 \& MSHE USR 3124, CNRS, Univ. Bourgogne Franche-Comté, F-25000 Besançon, France, boris.vanniere@univ-fcomte.fr

4 Archeobiology Group, Institute of History, CCHS, CSIC, Albasanz 26-28, 28037 Madrid, Spain, joseantonio.lopez@cchs.csic.es
} 


\section{Introduction}

In Greece, the question of whether cultural changes are due to social factors, environmental causes or human impact on the environment has been ongoing since the 1960s (Carpenter, 1966). The role of climatic oscillations or anthropogenic degradation of the environment on soil erosion and changes in vegetation cover has often been discussed as the main factors of socio-cultural changes. Since the 1970s, this issue has benefited from intensive fieldwork and palaeoenvironmental studies conducted in the Aegean world (e.g., Bintliff, 1977; Van Andel and Runnels, 1987; Van Andel et al., 1990; Van Andel and Zangger, 1990). In Northern Greece, palaeoenvironmental research has developed particularly during the last thirty years. As in the Mediterranean Basin, these have focused mainly in the dynamics of coastal environments (e.g., Ghilardi et al., 2008, 2012; Trianthaphyllou et al., 2010; Pavlopoulos et al., 2013), the role of society and climate on soil erosion and alluvial sedimentation (e.g., Krahtopoulou, 2000; Lespez, 2003, 2007) and more recently on the detection of global rapid climatic changes and their impact on human populations from the Neolithic onwards (Berger and Guilaine, 2009; Lespez et al., 2014, 2016; Berger et al., 2016; Glais et al., 2016a). After some preliminary investigations in the 1980s (e.g., Turner and Greig, 1975; Bottema, 1982), the issue of whether the landscape was shaped by Neolithic farmers became less of a focus but rather a problem of study still far from resolved, as underlined by the first synthesis and considerations of human impact on the landscape of continental Greece (e.g., Halstead, 2000; Ntinou, 2002; Lespez, 2008; Fouache and Pavlopoulos, 2011). These also point out the recent increase in archaeological investigations which have enabled archaeobotanical and zooarchaeological studies. Mainly focused on economy and diet, they nevertheless provide some valuable information on the shaping of the landscape by grazing and agricultural activities since the Neolithic (Sadori et al., 2010; Valamoti et al., 2007; Marinova 2009; Marinova and Valamoti, 2014; Pagnoux et al., 2015; Valamoti 2015). Unfortunately, its usefulness to reconstruct the history of the vegetation is limited because the remains of plants and fruits recovered by excavation are incomplete due to selection and differential preservation of plant macro-remains (López-Sáez et al., 2003). In this sense, the information obtained on an archaeological site must be also integrated with off-site palaeoenvironmental analyses (Sadori et al., 2010; Mercuri et al., 2013; Kouli, 2015; Glais et al., 2016a).

In this paper, we developed palaeoenvironmental and geoarchaeological investigations in the area surrounding an archaeological site under excavation in order to i) complement the archaeobotanical and zooarchaeological data obtained onsite; ii) identify evidence of human impact on the shaping of the landscapes; and, iii) propose an accurate landscape reconstruction following methods developed elsewhere with success (e.g., Groves et al., 2012; Brown et al., 2014). The study area is defined as the plain of Philippi-Drama, an area well-investigated by archaeological and geoarchaeological research in Northeast Greece (for a synthesis see Lespez, 2008). The focus is on the environment surrounding the Neolithic and Bronze Age site of Dikili Tash and the Macedonian to Byzantine city of Philippi. We present the results of sedimentological, palynological, and macroscopic charcoal analyses conducted to identify environmental changes resulting from human activity from the Middle Neolithic to Antiquity. We will discuss this in relation with the combined effects of the MidHolocene climate reversal and rapid climatic changes (RCCs) (Mayewski et al., 2004) that affected the Mediterranean world (Magny et al., 2013).

This investigation benefits from a local context well-known thanks to the high-resolution pollen record of Tenaghi-Philippon (Wijmstra, 1969; Greig and Turner, 1974; Turner and 
Greig, 1975; Pross et al., 2009; 2015; Muller et al., 2011; Peyron et al., 2011) and detailed knowledge of the regional vegetation dynamics during the Holocene (Willis, 1994; Willis and Bennett, 1994; Halstead, 2000). However, it is true that human impact detected during the Early Neolithic ca. 6400 cal BC in previous studies carried out on and off-site Dikili Tash (Glais et al., 2016a) cannot be easily extrapolated to a large regional scale, raising the question of the spatial representativeness of the different records. To overcome this problem and assess the impact of human activities on the landscape since the earliest phase of Neolithic settlement in the Southeastern Balkans, we have developed multi-scalar investigations. Indeed, we compare data obtained $2 \mathrm{~km}$ from Dikili Tash with data from the site itself as well as data obtained during previous research from the large Tenaghi-Philippon marsh located 5 $\mathrm{km}$ from the archeological site. The results cover the end of the Neolithic to the beginning of Antiquity, offering the possibility to describe local environmental changes associated with cultural changes occurring in Eastern Macedonia during these five millennia.

\section{Study area and archaeological background}

The Dikili Tash tell $\left(41^{\circ} 00^{\prime} \mathrm{N} ; 24^{\circ} 18^{\prime} \mathrm{E} ; 71 \mathrm{~m}\right.$ a.s.l) is one of the many tells in Northeastern Greece (Koukouli-Chryssanthaki et al., 2008) and one of the more extensive, with an area of over 4.5 hectares ( $250 \times 180 \mathrm{~m}$ at its base) and rising $17 \mathrm{~m}$ above the current ground surface (Fig. 1). The chronology of the occupation is well-known from several archaeological excavations since the 1960s (Treuil, 1992; Koukouli and Treuil, 2008; Darcque, 2013) and new discoveries indicate that the site was occupied since 6500 cal BC, making it one of the oldest Neolithic sites in Northern Greece and Southeastern Europe (Lespez, et al., 2013). The general setting of the site has been described in previous publications (Lespez et al., 2001). A permanent freshwater spring (monthly water flow between $2.4 \mathrm{~m}^{3} / \mathrm{s}$ and 15 $\mathrm{m}^{3} / \mathrm{s}$ ) is located directly northeast of the tell (Knithakis, 1983). From this spring, a stream flows into a narrow and gentle wetland valley towards the former large Tenaghi-Philippon marsh, constituted of peat deposits (Pross et al., 2015; Fig. 1). This large wetland area constitutes the southern part of the Philippi-Drama plain $\left(55 \mathrm{~km}^{2}\right)$. The plain is bounded by a succession of mountain ranges between $300 \mathrm{~m}$ a.s.l. (Symvolon) to $1956 \mathrm{~m}$ a.s.l. (Pangaion) composed of massive Mesozoic limestones or older crystalline rocks. This plain corresponds to a Neogene fault basin fringed by large Quaternary alluvial fans. The small valley studied was established between two quaternary alluvial fans and shows Late Quaternary deposits of layers rich in organic matter alternating with alluvial deposits (Lespez and Dalongeville, 1998; Lespez et al., 2001).

The climate regime is sub-Mediterranean with colder winters and wetter summers than the Aegean coastal area a few $\mathrm{km}$ southwards $(642 \mathrm{~mm}$ mean annual precipitation and $10.8^{\circ} \mathrm{C}$ mean annual temperature). Present-day vegetation on the surrounding mountains reflects the effects of both climate and human pastoral practices. As elsewhere in the Mediterranean world, agropastoral activities have left little of the original vegetation. On the lower mountain slopes, the main vegetation cover is a degraded phrygana/maquis including evergreen oaks (Quercus ilex and Q. coccifera), Phillyrea angustifolia, Rhamnus alaternus, Juniperus oxycedrus and Paliurus spina-christi. Some slopes have maintained woodlands composed of Quercus pubescens, Ostrya carpinifolia, Acer monspessulanum, Fraxinus ornus, Corylus avellana and some Fagus sylvatica and Abies cephalonica. The formerly extensive marshy area of Tenaghi-Philippon now consists almost completely of cultivated land, after 
the marsh was drained for land improvement during the 1930s, but the fields are largely flooded every winter by a rise in the water table.

Since 1961, the archeological site of Dikili Tash has been systematically investigated during successive research campaigns, producing a broad quantity of information on land use practices since the Neolithic (Lespez et al., 2001; Valamoti, 2004, 2015; Lespez, 2008, 2011, 2013; Darcque and Tsirtsoni; 2010). Over the last fifteen years, geoarchaeological research at Dikili Tash has provided additional data on the earliest Neolithic occupation level (Lespez et al., 2013, 2017) and the study area appears to have been an attractive environment during the Neolithic transition (Weninger, 2014; Berger et al., 2016). In fact, today there are a number of palaeoenvironmental evidences on the regional neolithization process (Glais et al., 2016a) that somehow contradict traditional models involving large migratory processes (Weninger et al., 2006, 2009, 2014; Berger and Guilaine, 2009). In the same way (Fig. 2), the palaeoenvironmental implications of the dense Late Neolithic settlement as well as short-term, economic and environmental circumstances of the Neolithic-Bronze Age cultural transition remain to be described (Koukouli-Chryssanthaki et al., 2008; Lespez, 2008). Similarly, landscape changes associated with transformations of the settlement during the Late Iron Age and Greek and Macedonian colonization are not as yet well-known due to the lack of palaeoenvironmental research for these periods. While archaeological and historical data show the development of the town of Philippi, dense regional settlement and significant economic and cultural changes (Koukouli-Chryssanthaki, 1998), the transformation of the environment suggested by the historical and archaeological data has not been assessed by the available palaeoenvironmental data (Lespez and Tirologos, 2004; Lespez 2008; Lespez, 2014; Izdebski et al., 2016).

Fig. 1. The tell of Dikili Tash on the edges of the former Tenaghi-Philippon marsh, the Philippi archaeological site and Dik4 core analyzed. Image from Google Earth $\left(40^{\circ} 58^{\prime} \mathrm{N}, 24^{\circ} 15^{\prime} \mathrm{E}\right)$.

Fig. 2. Archaeological context on the Philippi-Drama plain (Modified after Koukouli-Chryssantakhi et al. (2008).

\section{Materials and methods}

Reconstruction of landscape changes is based on precise study of the small valley of Dikili Tash which runs from the archaeological site to the edge of the Tenaghi-Philippon marsh (Fig. 1). The analyses have focused on the Dik4 core ( $3 \mathrm{~m}$ deep) located $1.75 \mathrm{~km}$ from the tell of Dikili Tash and $1.5 \mathrm{~km}$ from the ancient city of Philippi. It has beenobtained in September 2009 using a percussion device (Cobra TT). Sediment samples were collected in PVC tubes (diameter $60 \mathrm{~mm}$, length $1 \mathrm{~m}$ ), protected in plastic guttering and stored under cold conditions $\left(5^{\circ} \mathrm{C}\right)$ prior to laboratory description, subsampling (every centimeter) and analysis. In this paper, we present the second part of Holocene sedimentological sequence (the last meter) and macroscopic charcoal data since the end of the Pleistocene (two last meters). The palynological data show the vegetation cover changes from the Middle Neolithic to the beginning of the historical period. This corresponds to peaty and silty sediments between 30 and $110 \mathrm{~cm}$ deep on the Dik4 core. In a previous paper (Glais et al., 2016a) we present palynological data corresponding to the base of this record $(183-87 \mathrm{~cm})$.

\subsection{Sedimentological analyses and radiocarbon dating}


To describe the depositional context and post-depositional processes, accurate field observation and sedimentological analyses were conducted on the Dik4 core. Organic and carbonate analyses were conducted on 56 samples. The loss-on-ignition (LOI) method was used to estimate the organic content based following the method proposed by Dean (1974). Weighed relatively dry sediment samples of approximately $1 \mathrm{~g}$ were taken at less than $4 \mathrm{~cm}$ intervals through the 2-meter thick sequence. Changes in sedimentary features were taken into account to select the appropriate interval. After drying 24 hours at $105^{\circ} \mathrm{C}$ to a constant weight, the samples were then heated to $550^{\circ}$ for 3 hours to estimate organic content. $A$ second heating phase, to $925^{\circ} \mathrm{C}$ for 5 hour overtime, was done to assess the proportion of carbonate in the sediment.

Ten radiocarbon ages, spanning the section of interest, were used selected for ${ }^{14} \mathrm{C}$ AMS dating (Table 1) and used to produce an age depth model. The dates were calibrated using CALIB 7.1 with the IntCal13 curve (Reimer et al., 2013). The age depth model (Fig. 3) was produced using Clam 2.2 software (Blaauw, 2010). The best fit was obtained applying a smooth spline solution. Confidence intervals of the calibrations and the age-depth model were calculated at $95 \%(2 \sigma)$ with 1000 iterations. The calendar scale was cal BC/cal AD. The cultural chronology (Fig. 3 ) is provided in recent publications by the archaeologists (Tsirtsoni, 2016; Darcque and Tsirtsoni, 2010).

Table 1. Results of ${ }^{14} \mathrm{C}$ dating, showing calibrated age ranges $(2 \sigma)$.

Fig. 3. Age depth model of the Dik4 core (red line) and cultural chronology of the studied area. Black lines in the radiocarbon ages represent the $95 \%$ confidence and the area with the highest density ranges. EN: Early Neolithic; MN: Middle Neolithic; LNI: Late Neolithic I; LNII: Late Neolithic II; EBA: Early Bronze Age; MBA: Middle Bronze Age; LBA: Late Bronze Age.

\subsection{Pollen analysis}

Pollen analysis was carried out on 37 sub-samples of $1 \mathrm{~cm}^{3}$ along the selected core length (110-27 cm). Standard pollen extraction techniques were employed (Faegri and Iversen, 1989), although acetolysis was not carried out to allow the identification of any contamination by modern pollen. One Lycopodium tablet per sample was added in order to calculate pollen concentration (grains $\mathrm{cm}^{-3}$ ) (Stockmarr, 1971) and these values were divided by deposition time $\left(\mathrm{yr} \mathrm{cm}^{-1}\right)$ to calculate pollen accumulation rate (PAR; grains $\mathrm{cm}^{-2} \mathrm{yr}^{-1}$ ). Pollen counts of up to 400 grains total land pollen (TLP) per sample were identified and counted. Percentages were calculated based on TLP sum excluding wetland taxa and nonpollen palynomorphs (NPPs). Pollen grains, spores and NPPs were identified using palynological keys and photo atlases (Moore et al., 1991; Reille, 1992; van Geel, 2001; Cugny et al., 2010). Pollen diagram based on these data was produced using Tilia and Tilia-Graph v. 2.0.b.5 software (Grimm, 1992, 2004). Palynomorphs were then grouped according to their ecological affinities following Glais et al. (2016a). Local pollen assemblage zones (LPAZ) were defined on the base of agglomerative cluster analysis of incremental sum of squares (Coniss) with square root transformed percentage data (Grimm, 1987). To summarize the palynological, sedimentological and macro-charcoal data, a synthetic pollen diagram from time linear ordinate axis is proposed (Fig. 9). We undertook the merging of the species curves from there ecological affinities. The "anthropozoogenous" taxa refer to plants associated with grazing pressure in close relationship with anthropogenic activities such as livestock farming whereas "anthropic-nitrophilous" taxa refer to self propagading plants 
associated with disturbed nitrophilous soil and generally overrepresented in archaeological context but it's not directly crop plants (Behre, 1981; Bottema and Woldring, 1990; LopezMerino et al., 2009; Florenzano et al., 2012; Marinova et al., 2012). The xerothermophilous taxa gather mediterranean woodland and mediterranean scrubland together, composed of Pinus halepensis/picea type, Quercus evergreen, Quercus suber, Cistus type, Cytisus type, Erica arborea type, Juniperus type, Phillyrea and Pistacia lentiscus; Anthropozoogenous taxa include Plantago lanceolata type, Plantago coronopus type, Polygonum aviculare type and Urtica dioica type; Anthropic-nitrophilous taxa include Aster type, Cichorioideae, Asphodelus albus type, Asphodelus fistolosus type, Boraginaceae, Cardueae, Centaurea nigra type, Convulvulus, Malva sylvestris type, Papaver rhoeas type, Rubiaceae, Rumex acetosa type; Perennial pasture plants correspond with annual taxa from pasture, grassland or open meadows not necessarily resulting from anthropic activities. This group includes Apiaceae, Brassicaceae, Campanula type, Caryophyllaceae, Fabaceae undiff, Gentianella campestris type, Helleborus foetidus type, Jasione type, Primulaceae.

The NPPs groups (coprophilous, eu-mesotrophic, meso-oligotrophic, indicative of erosive processes, indicative of fire events or dry conditions) are performed regarding the ecological similarities and the specific NPPs study references cited (van Geel 2001; carrion and Navarro, 2002; van Geel et al., 2003; van Geel and Aptroot, 2006; Cugny et al., 2010; Gelorini et al., 2011, Kolaczek et al., 2013) confirm our choices. Coprophilous NPPs include Cercophora, Podospora, Sordaria, Sporormiella, Riccia, Coniochaeta cf. lignaria type; NPPs of eumesotrophic conditions include Ceratophyllum, Botryococcus, Spirogyra, HdV-18, HdV- 119, HdV- 120 and HdV-128A; NPPs indicative of erosive processes include Glomus cf. fascilicatum HdV-207 and Pseudoschizaea circula; NPPs indicative of fire or dry events include Pleospora, Chaetonium and Neurospora.

\subsection{Macro-charcoal analysis}

Contiguous samples of 2 to $4 \mathrm{~cm}^{3}$ were retrieved by volumetric displacement at $1 \mathrm{~cm}$ intervals, soaked in a $10 \% \mathrm{NaOH}$ solution for $24 \mathrm{~h}$ for peat digestion, then in a $6 \% \mathrm{H}_{2} \mathrm{O}_{2}$ solution for the same time to bleach non-charcoal organic material and thus make charcoal identification easier (Rhodes, 1998). As the aim is to reconstruct local fire history, quantification of charred particles was done by sieving with a $150-\mu \mathrm{m}$-mesh size (Whitlock and Larsen, 2001; Vannière et al., 2008). Charcoal identification is based on the criteria defined in the literature (Umbanhowar and McGrath, 1998; Enache and Cumming, 2006). Charcoal particle concentration (particle $\mathrm{cm}^{-3}$ ) was estimated under a binocular microscope at a $40 \times$ magnification with a reticule grid of $10 \times 10$ squares of $250 \times 250=62500{\mu \mathrm{m}^{2}}^{2}$ each. Charcoal Influx was expressed as CHarcoal Accumulation Rate (CHAR; particle. $\mathrm{cm}^{2} . \mathrm{yr}^{-1}$ ) based on Sedimentation Accumulation Rate (SAR) estimated by the age-depth model. The slowly varying signal tendency of the charcoal record influx values were smoothed with a robust locally weighted regression type (Lowess function) with a 500-year time frame that best fits the low frequency variation. This tendency may be linked to fuel availability and characteristics (Marlon et al., 2006; Vannière et al., 2016) or regional fire activity (Whitlock and Larsen, 2001). Peaks above the tendency express fire episodes in the local or microregional area around the marsh (Long et al., 1998; Vannière et al., 2008). Four classes were defined: "small" and "large" types correspond respectively to particles less than and greater than $62500 \mu \mathrm{m}^{2}$; "unbreakable" types correspond to particles with a massive squared or 
rounded shape; the "breakable" type includes particles with a high irregular porosity or an elongated shape with a length vs. width ratio greater than about 3. Large particles can be regarded as a good indicator of local fire episodes (Whitlock and Larsen, 2001). Breakable type particles indicate an unaltered or "direct" signal, i.e., particles that have been deposited in the marsh during or soon after the fire episodes (Vannière et al., 2003; Enache and Cumming, 2006). The elongated shape may be also related to the type of fuel burnt: grass for the highest length vs. width ratio (Umbanhowar and McGrath, 1998).

\section{Results}

\subsection{Description of the sedimentary sequence}

The sedimentary sequence for the Dik4 core has been partially described in Glais et al. (2016a). The core as a whole corresponds to organic clay and silt typical of the edges of the Tenaghi-Philippon marsh. The first $100 \mathrm{~cm}$ studied in this paper are presented in figure 4 . From the bottom, the first unit (U1) between 100 and $98 \mathrm{~cm}$ is whitish silt. It is covered by a silty gyttja (U2a, c, e) interrupted by a lighter colored deposits with less organic detritic content between $90.5-90 \mathrm{~cm}$ (U2b) and a brown-ochre silt layer between $72-65 \mathrm{~cm}$ (U2d). The detritic layers reflect sedimentary input from the piedmonts and the Dikili Tash valley. From $52 \mathrm{~cm}$, the silty sediment becomes lighter and brown (U3). The silty gyttja have a high organic content generally comprised between 10 and $20 \%$ and two peaks with a higher content $(30 \%)$ are identified at $89 \mathrm{~cm}$ and $58 \mathrm{~cm}$. The carbonate content is homogenous and low (less than 5\%). The top unit (U4) is characterized by a significant decrease in organic content and an increase in carbonate (up to 20\%) related to a high detritic input from the flood flows of the stream of Dikili Tash and corresponding to an acceleration of sedimentation on the edge of the marsh (Fig. 5).

Fig. 4. Synthetic log of Dik4: sedimentary facies, accumulation rates, LOI and carbonate content percentages.

\subsection{Fire history}

The macro-charcoal record (Fig. 5) is typically dominated by the smallest and squared or rounded (unbreakable) particles that could be reworked and do not necessarily evidence fire occurrences (Enache and Cumming, 2007). Associated with these, large and/or fragile (breakable) particles appear only in discrete intervals in the record and may support the fire history reconstruction in the area surrounding the core (Vannière et al., 2003; Enache and Cumming, 2006). Thus, the fire history inferred from the sedimentary macro-charcoal content highlights four main phases of increase in fire activity and eight short-lived fire episodes that are indicated by grey-bands on Fig. 5. Between ca. 11800 and 8500 cal BC, only five punctual fire episodes are detected in the CHAR signal by "Large-Unbreakable" particles. These indicate limited biomass burning during the last Glacial-Interglacial transition (BöllingAlleröd) and no fire has been detected during the Younger Dryas period (10700-9600 cal BC) in this area. The first fire real activity increase is recorded during the Early Holocene from 8500 to $7300 \mathrm{cal} \mathrm{BC}$. It is characterized by high total CHAR values, a general increasing trend and the deposition of "Large-Breakable" particles in addition to an increase in the amount of "small-breakable" particles. All of these proxies meaningfully reflect local biomass burning during a period that spans 1300 years, and corresponds to the Mesolithic in this region. A second phase of episodic fire occurrences is then recorded, with only three charcoal peaks detected over a period of 2800 years (between 7300 and $4500 \mathrm{cal} \mathrm{BC}$ ). These are dated to 
ca. 6500,6100 and 5650 cal BC, i.e., during the first Early Neolithic occupation of the nearby Dikili Tash tell (Lespez et al., 2013; Glais et al., 2016a). Next, the charcoal series shows a return of long-term biomass burning with almost two millennia of CHAR trend increase (between 4500 and 2500 cal BC), also recorded by the Large-Breakable charcoal-type and overrepresented by peaks in the Large-Unbreakable charcoal type, which attest to local repeated fire episodes. No fire episodes are recorded during a short period, between 2500 and $1900 \mathrm{cal}$ BC. The third phase of fire activity increase is characterized by the highest magnitude of sedimentary charcoal influx values in the record, both in total CHAR and in large charcoal-type fire episodes. This phase spans around a millennium until 900-800 cal BC and corresponds to the Bronze and Iron Age occupations. Again, no fire episodes are detected between 850 and 50 cal BC when the CHAR record drops and rises abruptly. Finally, the last biomass burning phase documented by this record covers only two centuries (ca. 100 cal BC-cal AD 100) with high magnitude CHAR values.

Fig. 5. Macro-charcoal analysis from Dik4 core. Light-grey bands correspond to short-lived fire episodes while dark-grey bands indicate main phase of fire activity.

\subsection{Vegetation history}

Fig. 6. Trees and Shrubs pollen diagram from Dik4 core. Light color curves result from a tenfold exaggeration of the original curves. Species values comprising 0.5 and $1 \%$ are represented by points. Species percentages below $0.5 \%$ are not represented.

Fig. 7. Herbs pollen diagram from Dik4 core. Light color curves result from a tenfold exaggeration of the original curves. Species values comprising 0.5 and $1 \%$ are represented by points. Species percentages below $0.5 \%$ are not represented.

Fig. 8. Hydro-hygrophytes and NPPs pollen diagram from Dik4 core. Light color curves result from a tenfold exaggeration of the original curves. Species values comprising 0.5 and $1 \%$ are represented by points. Species percentages below $0.5 \%$ are not represented. Taxa are expressed as percentages compared to the total land pollen sum.

The results of identification and counting of pollen grains, spores and NPPs are presented as three distinct percentage diagrams (Figs. 6, 7 and 8). The sequence was divided into six local pollen assemblages zones (LPAZ). A synthetic pollen diagram is also proposed (Fig. 9) to correlate selected pollen and NPPs percentage curves with LOI, carbonates and macrocharcoal influx data for the time frame ca. 6800 cal BC-cal AD 300.

The five lowermost samples (LPAZ1, $110-99 \mathrm{~cm}$, ca. 6800-5600 cal BC) reflect a sparse alder forest (Alnus 25\%) surrounding the site with abundant anthropic-nitrophilous taxa $(20 \%)$ and Poaceae (9\%) in the understory. Deciduous and evergreen Quercus, Juniperus and Pinus sylvestris pollen types are low $(<7 \%)$. This zone is also characterized by rapid accumulation of charcoal (Figs. 5 and 9 ).

LPAZ2 $(99-91 \mathrm{~cm})$ covers the time period from ca. 5600-4550 cal BC, which corresponds mainly to the Late Neolithic I and the beginning of the Late Neolithic II. Alnus percentages are high (>60\%), indicating a dense alder forest in the vicinity corresponding to a landscape closing by arboreal riparian vegetation on the edge of the Philippi marsh. At the same time, the percentages of hydro-hygrophytic taxa and NPPs indicative of eu-mesotrophic conditions decrease, respectively from 18 to $7 \%$ and 7,5 to $2 \%$ (Fig. 9). The presence of NPPs indicative of erosive processes remains at a relatively high value, reflecting high carbonate input from 
the streams at the beginning of the period. The erosive processes on the slopes coincide with the deposition rate acceleration. The location of Dik4 at the interface between the marshy environment and the piedmont explains why no similar change was detected in the investigations conducted in the middle of the marsh during this time period (Greig and Turner, 1974). Other components, such as deciduous Quercus and Juniperus also increase. Macro-charcoal particles are present in low concentration. The increase of coprophilous NPPs and anthropozoogenous pollen taxa indicate some type of localized pastoral pressure. Cerealia type occurs in the uppermost pollen spectra above $92 \mathrm{~cm}$ depth, corresponding to the first palynological manifestation of agricultural activities ca. $4550 \mathrm{cal}$ BC during the Late Neolithic II.

The overlying LPAZ3 zone (91-85.5 cm, ca. 4550-3900 cal BC) is dated to the last phase of the Late Neolithic II, sometimes called the Final Neolithic or Chalcoltihic (Tsirtsoni, 2016). The percentage values of Alnus diminish from 80 to $25 \%$ and those from Poaceae, anthropicnitrophilous and anthropozoogenous taxa increase. Further, we observe the first appearance of Castanea pollen grains. The macro-charcoal influx ( 25 particles $\mathrm{cm}^{-2} \mathrm{yr}^{-1}$ ) is higher than those of the LPAZ2 zone, suggesting enhanced fire. Hydro-hygrophytic taxa and eumesotrophic NPPs reach higher values. Coprophilous NPPs reach a maximum (5\%).

The LPAZ4 zone (85.5-61.5 cm; ca. 3900-1750 cal BC) is characterized by extensive forest clearing with significant oscillations and decreasing levels of Alnus (35 to 13\%). It covers the Late Neolithic II and the Early and Middle Bronze Age. Other arboreal pollen percentages increase (deciduous Quercus, Pinus sylvestris), while Juniperus decreases above $80 \mathrm{~cm}$. This zone is also characterized by synchronous increases of hydro-hygrophytic elements and xerothermophilous taxa.. These conditions seem to have favored the continuous presence of olive trees. Eu-mesotrophic NPPs and coprophilous NPPs continue to be present. At the beginning of the zone (ca. 3900-3670 cal BC), a distinct rise in Cerealia type, in combination with synchronously higher values of macro-charcoal and the spread of Poaceae, perennial pasture plants, anthropic-nitrophilous and anthropozoogenous taxa, reflects the clearing of local arboreal cover during the last phase of the Late Neolithic II. Next, until ca. 2915 cal BC (beginning of the Early Bronze Age), the landscape was half-opened and the fig. 8 record a continuous curve of coprophilous NPPs as well as settlement indicators (anthropicnitrophilous taxa) and the absence of cereal pollen grains. After this date, fire activity is reduced and Cerealia type reappear and was recorded until the end of the zone ca. $1750 \mathrm{cal}$ BC (Middle Bronze Age).

With the onset of LPAZ5 $(61.5-49 \mathrm{~cm})$, from the beginning of the Late Bronze Age ca. 1650 cal BC until the beginning of the Iron Age ca. 1000 cal BC, the forest dynamic appears related to a sudden decrease in the percentages of Alnus $(<5 \%)$ with the definitive opening of the alder forest, in parallel to increases in xerothermophilous taxa and Poaceae. The increase of eu-mesotrophic NPPs (until 19\%) show the existence of a semi-permanent body of shallow water rich in nutrients. The intensification of local fire regimes is also remarkable by increasing macro-charcoal values. The presence of anthropic-nitrophilous taxa (mainly Aster type and Cichorioideae) during the Late Bronze Age (ca. 1650-1000 cal BC) is lower than previous zone.

The LPAZ6 zone (49-27 cm; ca. 1000 cal BC-cal AD 300) reflects the continued degradation of alder forest (1-2\%) since the Iron Age ca. 1000 cal BC and encompass the Antiquity. In this zone, anthropic-nitrophilous (Aster type, Rumex acetosa type and Cichorioideae) and anthropozoogenous taxa (Urtica dioica type and Polygonum aviculare type), Poaceae and perennial pasture plants (Brassicaceae, Fabaceae and primulaceae) culminate with 
maximum values through the entire pollen record. At higher altitudes, Pinus sylvestris and Juniperus spread. In the top samples $(45-27 \mathrm{~cm})$ there are noticeable peaks for Cerealia type and coprophilous NPPs. In addition, the values of macro-charcoal increase, suggesting fire activity in the surroundings.

\section{Discussion}

5.1. From the Late Pleistocene to the emergence of an agricultural landscape during the Late Neolithic (ca. 11800-3900 cal BC)

Previous palynological research undertaken in the Dik4 core (Glais et al., 2016a) and in other parts of the Tenaghi marsh (Kotthoff et al., 2008, 2011) demonstrate the existence of an open landscape dominated by herbaceous communities and steppic taxa and a very small tree cover during the Lateglacial period (ca. 11800-8500 cal BC). These data agree with the macro-charcoal record of Dik4 (Fig. 5) where only sporadic and low intensity fire episodes are detected indicating limited biomass burning. Instead, the beginning of the Holocene is characterized by a general increasing trend in macro-charcoal values from ca. 8500 to 7300 cal BC (Fig. 5), reflecting local biomass burning related to long-term changes in vegetation composition with the large development of arboreal vegetation (Glais et al., 2016a). In any case, these changes are linked to climatic dynamics (i.e., climatic amelioration on the onset of the Holocene related to warmer conditions) occurred across a broad part of Greece (Wijmstra, 1969; Turner and Greig, 1975; Digerfeldt et al., 2000; Lawson et al., 2004) but not with human noteworthy activity (Glais et al., 2016a).

Previous palynological analyses from the Tenaghi-Philippon marsh (Wijmstra, 1969; Greig and Turner, 1974; Kotthoff et al., 2008) report that the Philippi region was thickly covered by mixed-oak forest with few glades for the time span 8500-2500 cal BC. However, recent investigations on the northeastern edges of this marsh have provided evidence of an environment locally considerably more open during the Early Holocene (Glais et al., 2016a). In particular, the edge of the marsh was characterized by wet and fallow lands and meadows prior to 7000 years BC. Further, even if agricultural practices are not detected on the edge of the marsh (Dik4 core), they were indicated at the base of the site of Dikili Tash (Dik12 core) during the Early Neolithic ca. 6500-5700 cal BC (Glais et al., 2016a). These facts corroborate the data provided by the macro-charcoal study presented in this paper (Fig. 5), in which two maximum peaks are detected ca. 6500 and 6100, probably related to anthropogenic activities developed by the first Neolithic occupation of the nearby Dikili Tash tell.

The first cultural period studied in detail in this paper, from a palynological point of view (Fig. 6), extends from ca. 6700 to 5600 cal BC (LPAZ1) and corresponds to the Early and Middle Neolithic in the region, for which Dikili Tash is the only site as yet known (Lespez et al., 2013). Pollen data from Dik4 confirm the densification of riparian vegetation dominated by alder (Alnus) but give no indication of anthropogenic change of the land cover except the presence of coprophilous NPPs; although at this time a new maximum peak is detected in the macro-charcoal values ca. $5600 \mathrm{cal} \mathrm{BC} \mathrm{(Fig.} \mathrm{5).} \mathrm{We} \mathrm{can} \mathrm{assume} \mathrm{that} \mathrm{herds} \mathrm{were} \mathrm{kept} \mathrm{at}$ the surrounding of the settlement in the marsh border (Dik4), and probably the use of fire to clear the forest (López-Sáez et al., 2000; López-Sáez and López-Merino, 2007). In any case, the high values of alder mask these facts (Glais et al., 2016a). 
The regional settlement then increases with more than 25 sites known for the Late Neolithic ca. 5500-3900 cal BC (Koukouli-Chryssanthaki et al., 2008). The geographical permanence, although discontinuous, of the settlement over more than 1500 years, questions the topographical, pedological and hydrologic characteristics which probably have been not always key factors for prehistoric societies to stimulate settlement. At Dikili Tash, several factors play a significant role in the persistence of the site. First, access to water resources is crucial. Dikili Tash is located less than $100 \mathrm{~m}$ from a permanent karstic spring and many sites on the Philippi-Drama plain are located immediately next to a spring, stream, pond or lake (Figs. 1-2). This observation is widespread and has been made for Neolithic sites in western Macedonia (Lespez, 2008; Karkanas et al., 2011; Kouli and Dermitzakis 2008; Kouli, 2015; Gkouma et Karkanas, 2016), Northwestern Anatolia (Boyer et al., 2006; Groenhuijzen et al., 2015; Stock et al., 2015) and the Balkan region generally (Filipovic et al., 2014). On the contrary, the defensive character of the Dikili Tash site was not a priority because more than half of the Late Neolithic sites on the Philippi-Drama plain are flat, unprotected sites located on the gentle slopes of the piedmont (Lespez, 2008). As observed at Dikili Tash, the inhabitants chose to settle only at low elevations between 1-5 $\mathrm{m}$ above the alluvial zone (Lespez et al., 2013; Groenhuijzen et al., 2015; Stock et al., 2015). This position provided safety against water level fluctuations and flood flows of torrential streams (Renfrew et al., 1986; Filipovic et al., 2014; Schneider et al., 2014; Stock et al., 2015). In the case of Dikili Tash, as for others on the Philippi-Drama plain or long-duration sites in the Eastern Mediterranean area, such as Çatal Höyuk (Schneider et al., 2014), additional considerations as strategic position should be taken into account. Indeed, the site is at the narrowest passage $(300-400 \mathrm{~m}$ ) between the Lekani mountains and the Tenaghi-Philippon marsh. But the more important factor with respect to water resources is likely its position at the interface between the alluvial plains or large wetlands, consisting of brown leached soils (luvisol) of the distal parts of alluvial fans, and the lower slopes of the surrounding mountains. This location at the boundary of different landscape units offers access to complementary resources.

Despite the occupation of Dikili Tash during the 5500-4550 cal BC period which corresponds mainly to the first phases of the Late Neolithic-LNI (Treuil et al., 2008), the impact of agropastoral activities are difficult to detect on the edge of the marsh prior to the mid-5 $5^{\text {th }}$ millennium BC (LPAZ2; Fig. 6). The abrupt densification of riparian vegetation, dominated by Alnus, led to a closed landscape that entirely conceals evidence of possible human impact (Glais et al., 2016a). Yet, the occurrence of coprophilous NPPs is an indicator of animal browsing and pastoralism that seems to remain a significant activity in the vicinity of the tell like during the Middle Neolithic (LPAZ1), similar also to that observed at Dispilio in western Macedonia (Kouli, 2015). Low values of macro-charcoal (Fig. 5) agree also with lower human impact.

It is only around 4550-3950 cal BC (LPAZ3), during the second phase of the Late Neolithic (LNII), that the development of anthropogenic indicators is observed as the sudden and complete decline of alder without correlation to a regional climatic episode (Kohttoff et al., 2008). Simultaneously, the Dik4 sequence show the appearance of cereals, sweet chestnut (Castanea), and a peak of coprophilous NPPs, anthropic-nitrophilous and anthropozoogenous taxa (Fig. 6). This is correlated with the identification of stored cultivated crops on the site of Dikili Tash, including einkorn (Triticum monococcum), naked barley (Hordeum vulgare var. nudum), lentil (Lens culinaris), bitter vetch (Vicia ervilia), grass pea (Lathyrus sativus) and flax (Linum usitatissimum) (Valamoti, 2004, 2015). Further, 
zooarcheaological research has assessed livestock management (mainly cattle and pig) from the Late Neolithic (Jullien 1992; Helmer 1997). In this sense, on-site (Dikili Tash) and off-site (Dik4) data confirm the development of agricultural practices. The appearance of Cerealia type ca. 4550 cal BC in the Dik4 pollen record corresponds with the first indications of cultivation almost $2 \mathrm{~km}$ from the settlement. This indicates a large expansion of cultivated fields around the Late Neolithic village (López-Sáez and López-Merino, 2005; Marinova et Ntinou, 2017). It is also associated with the beginning of the first long-term biomass burning, with almost two millennia of an increasing CHAR trend, attesting to repeated local fire episodes and the highest peak of "Large-Unbreakable" CHAR recorded in the Dik4 core since the Lateglacial (Fig. 5). The role of fire in landscape modification may also be proposed. As observed at Dispilio site in western Macedonia (Kouli and Dermitzakis, 2008), Scots pine and alder dominating the woodland were also affected because their trunks were used for dwelling construction as demonstrated by the anthracological study of wood remains (Ntinou 2002; Marinova et Ntinou, 2017). According to Zohary (1996), the previous so-called Neolithic Near Eastern "crop package" consists of a dominance of einkorn (Triticum monococcum) seeds, as well as emmer (Triticum dicoccum), hulled barley (Hordeum vulgare), lentil (Lens culinaris), pea (Pisum sativum), bitter vetch (Vicia ervilia), chick pea (Cicer arietinum) and flax (Linum usitatissimum), the latter probably exploited for fibers. Investigations conducted at Dikili Tash show the lasting success of this package and are in agreement with data obtained in western Anatolia, at Illipinar (Cappers, 2008), Aktopraklik (Budd et al., 2013) and Burdur province (De Cupere et al., 2017), which show the same broad spectrum of plant resources during the Neolithic and Chalcolithic phases and later. A similar pattern of early signs of cultivating and grazing activities has been observed in other pollen diagrams in the Balkan area during the Late Neolithic. These show small amounts of cereal pollen and an increase in weed (Cichorioideae, Rumex acetosa, Ranunculus acris) and edible species (Brassicaceae, Leguminosae, Chenopodiaceae, Apiaceae) (Kouli and Dermitzakis, 2008). The plant economy of sites situated south of the Balkan Mountains reflects homogeneity in terms of crop plant composition, wild resources exploited and weeds associated with the fields (Marinova, 2009). Clearance resulted in the increase of open ground herbaceous types with other anthropogenic indicators, called "secondary anthropogenic indicators" in the Mediterranean region and Greece (Behre, 1981; Bottema, 1982; Bottema and Woldring, 1990; Marinova et al., 2012). This includes pollen types either directly or indirectly associated with human activity, such as those of cultivated plants, weeds and plants associated with grazing, overgrazing, stock-breeding and human creation of pastures (Cerealia type, Olea, Vitis, anthropic-nitrophilous and anthropozoogenous taxa). Other plants are characteristic of human impact on natural vegetation from fires and clear cutting, among other activities (Juniperus, Artemisia, Chenopodiaceae) as proposed by Gerasimidis (2000). Archaeobotanical research conducted on the Dikili Tash site shows that in the Late Neolithic (5500-3900 cal BC), food collecting activities still persisted (hunting, gathering), but were complemented and then replaced by complex agricultural and pastoral practices (Valamoti, 2015).

Further details are provided by the gathered food products. In fact, wild fruits and nuts are found in relative abundance in the Late Neolithic levels of Dikili Tash. They show a wide spectrum of wild collected plants, indicating an increasing variety in diet and subsistence resources (Valamoti, 2015). Despite the ideological dichotomy between "wild" and "domesticated" resources encountered in the archaeological literature (Hodder, 1990), rather than being ostracized from early farming subsistence activities, gathering in the wild 
may have made a significant contribution to diet and the symbolic systems of early farming communities Valamoti (2015). Grape pips directly dated to 4460-4000 cal BC find on the tell suggest that they were morphologically wild (Mangafa and Kotsakis, 1996). Pyrus amygdaliformis, a wild fruit tree, would probably have grown in patches of managed open woodland vegetation or clearings or even within crop fields near the settlement, as it requires well-drained soils with open or cleared vegetation and ample light to yield fruit. According to Bottema (1980), the appearance of Castanea occurred later, almost certainly from introduced trees. It was present in the Balkans during the Lateglacial (Wijmstra, 1969; Bottema, 1974; Filipovitch, 1977) and expanded locally as a result of a favorable niche being created by anthropogenic disturbance (Gerasimidis 2000). Fig trees also require open, sunny spots, and would have flourished both in riverside environments as well as dry areas with underground water. Based on the archaeobotanical finds from Dikili Tash, natural woodlands surrounding the settlement would have been intensively managed and transformed. Wild fruit trees would have been encouraged or even cultivated in some cases. Grape vines around Dikili Tash could have been tended, managed, husbanded, or even cultivated, despite their morphological resemblance to wild ones. Among Neolithic farming societies of northern Greece, crop fields would have required constant tending, with soil preparation, managing, weeding, sowing, etc. (Halstead 2000). What is certain from the plant remains and palynological data is the intensive use of the "wild" non-arable vegetation surrounding the site (Valamoti 2015). Such intensive interference with woodland vegetation in the vicinity of Dikili Tash, although of a scale undetectable by regional pollen diagrams, seems to be indicated in recent environmental proxies from the periphery of the settlement (Glais et al., 2016a). According to Filipovic et al. (2014) at the Vinča tell (Bulgaria), the abundance and careful management of natural resources may have been the key to the longevity of the site even if the relationship with parts of the landscape comprising fruit and nut-yielding wild trees is more obscure. It has been suggested that the subsistence economy of the settlement relied on a combination of crop and animal husbandry, supported by wild plant gathering and hunting/fishing.

Change in production systems is relatively well-supported by archaeological data on a regional scale (e.g. Renfrew et al., 1986; Lespez, 2008; Darcque, 2013), but its effects on the landscapes surrounding the tell appear to have had a clear radical impact from ca. $4550 \mathrm{cal}$ BC (LPAZ3; Fig. 6). Data obtained from Dikili Tash show at this time the subsistence practices adopted by Neolithic farmers had progressively transformed the landscape within a radius of at least $2 \mathrm{~km}$ around the settlement during the second phase of the Late Neolithic (45003900 cal BC). Contradicting an early hypothesis (Bintliff, 1977), the farmers of Dikili Tash did not exploit light alluvial soils but rather the heavy rich soils of the distal part of the alluvial fans and the edge of the marsh. It is not yet possible map the fields and the distribution of the cultivated crops during the Late Neolithic. But the weed flora and self-propagating plants, as well as anthropic-nitrophilous and anthropozoogenous taxa in the palynological assemblage, indicate that agriculture created a mosaic of landscape units combining open landscapes with grazing and farming activities, fallow lands and secondary forest patches or vestigial original forest. This suggests that human modification of the vegetation was gradual and localized, as observed elsewhere in the Southern Balkans (Marinova, 2009). These observations are consistent with the results of studies of Neolithic wood charcoal assemblages from Northern Greece (Ntinou and Badal, 2000). Widespread settlement during the Late Neolithic is further evidenced by archaeological research and its impacts on vegetation very likely affected the landscape around each Late Neolithic settlement on the 
Philippi-Drama plain. It implies significant regional-scale change even though the impact of human activities on the vegetation is not recorded in the middle of the Tenaghi-Philippon marsh (Greig and Turner, 1974). The change is confirmed at the regional scale by pollen data from the Lower Strymon valley about $50 \mathrm{~km}$ to the west (Lespez et al., 2016).

Fig. 9. Synthetic pollen diagram of selected taxa, time linear, correlated with LOI, carbonate content and macro-charcoal influx from Dik4. Light color curves result from a tenfold exaggeration of the original curves

\subsection{The transition Late Neolithic-Bronze Age (ca. 3900-1650 cal BC). Towards diversified agricultural landscapes}

Following the first aforementioned period of human impact on the landscape due to agropastoral activities during the Late Neolithic II, between 3900 and 3300 cal BC a rapid increase in oak, alder and pine values and a decrease in indicators of human impact and grazing activities are seen in the Dik4 pollen record (bottom of LPAZ4; Fig. 6), as also has been observed in the Lower Strymon valley (Lespez et al., 2016). This may be related to the abandonment of the archaeological site of Dikili Tash. Indeed, at Dikili Tash (Darcque et al., 2013), as for most of archeological sites excavated in the Southern Balkans, abandonment is observed during the end of the Late Neolithic (LNII) from around ca. 3900 to 3300 cal BC (Tsirtsoni, 2016). However, the constancy of a fire signature (continuous macro-charcoal values), the occurrence of anthropozoogenous and anthropic-nitrophilous taxa, and the development of olive trees ca. 3900-3300 cal BC, as well as the presence of Cerealia type ca. 3900-3650 cal BC in Dik4 pollen record (Fig. 9), suggest the persistence of agropastoral activities in the surroundings of the site. As in the Lower Strymon valley (Lespez et al., 2016), we hypothesize that the last Neolithic populations moved from the former site of Dikili Tash after 3900 cal BC but continued to be present on the Philippi-Drama plain and practiced agropastoral activities until $3300 \mathrm{cal} \mathrm{BC}$. After ca. $2900 \mathrm{cal} \mathrm{BC}$, the reappearance of Cerealia type, increases in anthropic-nitrophilous taxa, Olea, Poaceae and macro-charcoal values suggest a new development of agropastoral activities during the Early Bronze Age that continued until ca. 1650 cal BC (bottom of LPAZ5; Fig. 5) at the end of the Middle Bronze Age. In fact, from 3200 cal BC, the settlement of Dikili Tash has been assessed (Darcque et al., 2014), indicating that most of the Late Neolithic tell was reoccupied during the Early Bronze Age (Treuil et al., 2008, Fig. 2) and explaining an increase in settlement after a gap of several centuries (at least 3900-3200 cal BC). This led to a new chapter of anthropogenic changes to the landscape. The archaeaobotanical data obtained from the few sites excavated, including Dikili Tash (Treuil et al., 2008), show the increase of wheat at the expense of barley and the cultivation of millet (Panicum miliaceum). Millet is a cereal crop which probably played an important role during the Late Bronze Age in Greece (Marinova, 2009), while leguminous crops or pulses were still very important group of cultivated plants grown in the area throughout the Late Neolithic and the Bronze Age (Marinova and Valamoti, 2014). In the off-site data (Dik4), we observe maximum values of anthropicnitrophilous taxa from 2300 cal BC which can be associated with these crops.

Other crops yielding seeds rich in oil have also been identified from Bronze Age contexts in Greece, but not in Bulgaria. These crops are opium poppy (Papaver somniferum ssp. somniferum), Brassica sp. and Camelina sp., suggesting a rather wide variety of crops potentially used for oil in the Bronze Age in Northern Greece (Jones and Valamoti, 2005). The first two are included in anthropic-nitrophilous taxa and the third included in perennial pasture plants (Fig. 6), which could confirm this hypothesis at the local scale during the Early 
and Middle Bronze Age. Grape and olive have been closely linked with prehistoric communities in Greece. Even though the climate of Northern Greece is not favorable for olive cultivation, from the second half of the $4^{\text {th }}$ millennium cal BC, shortly after the first identified Cerealia type pollen grain, a continuous curve of Olea pollen is recorded. It suggest that olives may have been exploited around 3350 cal BC as in southern Greece (Kouli 2012; Weiberg et al., 2016) or on the nearby Strymon delta $(50 \mathrm{~km})$ where the records for Olea pollen probably come from wild trees growing in the rich maquis of Macedonia (Atherden et al., 2000). Concerning grape, the issue of whether it was cultivated or not also remains unresolved, although archaeobotanical analyses from Bronze Age sites suggest that morphologically domesticated pips were present, thus making cultivation a strong possibility (Marinova and Valamoti, 2014; Valamoti, 2015). In Dik4 pollen record, Vitis was only identified by two pollen grains during the Early-Middle Bronze Age, which is not sufficient to demonstrate such cultivation; the same is true for the first appearance of Juglans pollen, recorded around $3400 \mathrm{cal} B C$.

The riverside vegetation (alder forest) and the remaining mixed oak forest of the slopes shown in the pollen diagrams for the center of the marsh (Greig and Turner, 1974) would have offered abundant food sources for collecting and forage for livestock, as well as suitable conditions for wild fauna, largely represented in the bone remains at Dikili Tash (Darcque et al., 2009), as also seen at Vinça (Orton, 2012). For the domestic fauna, the zooarchaeological observations at Dikili Tash show the dominance of domesticated pigs and cattle over sheep and goat during the Bronze Age, a typical pattern seen also in Macedonia and in the Southern Balkans (Jullien 1992). On the Philippi-Drama plain, at Sitagroi (Bökönyi 1986), Dimitra (Yannouli 1991) and Dikili Tash (Jullien 1992), the significance of pig has been examined for the Bronze Age. Given the low representation of coprophilous NPPs recorded in Dik4 ca. 3950-1750 cal BC (LPAZ4; Fig. 9), it is probable that the highest pastoral pressure was not on the edge of the Tenaghi-Philippon marsh but closer to the inhabited areas. The continuity of the fire signature during the period (Fig. 5) also suggests that pasture fields were burned to maintain an open landscape and to renew the herbaceous vegetation, likely near the site or on the lower slopes of the mountains.

Together these observations show that the anthropogenic impact on the landscape became widespread with the onset of the Bronze Age, as seen by the continuous decrease of forest cover recorded on the edge of the marsh (Dik4), but also and for the first time from pollen diagrams obtained from the middle of the marsh (Greig and Turner, 1974) since the Middle Bronze Age. While previous studies of the Balkans (Willis, 1994) indicate a decrease in forest vegetation from about $2050 \mathrm{cal} \mathrm{BC}$, or $1450 \mathrm{cal}$ BC in the mountainous areas of Bulgaria (Marinova et al., 2012), the new data discussed here confirm large-scale clearances detected ca. 3200-3000 cal BC in Northeastern Greece (Lawson et al., 2004), in the Peloponnese (Southern Greece) with the Early Helladic period (Weiberg et al., 2016) and in the large Eastern Mediterranean region (Roberts et al., 2011). Further, agrosystems became more complex as indicated by a greater diversity in cultivated plants.

The pollen studies also reflect a regionally diversified land management system. Indeed, despite similarities in general trends, it is becoming apparent that we are not dealing with a uniform crop pattern throughout Southeastern Europe, Greece and Bulgaria in particular, but with noticeable regional differences as suggested by Marinova and Valamoti (2014). For example, in nearby Thracian Bulgaria, Connor et al. (2013) show that the fire frequency appears to have increased towards the end of the oak forest phase around 3550-2050 cal $\mathrm{BC}$, reflecting a pattern observed across the Eastern Mediterranean region (Vannière et al., 
2011), while the signal observed in the Dik4 core is not similar and suggests a low frequency of fires during the period ca. 3000-1650 cal BC (Figs. 5-9). Thus, the use of the fire signal to detect RCCs should be used with caution from at least the Early Bronze Age; it is more probably linked with human activities (Vannière et al., 2016).

In addition, the data from the Dik4 core also suggest the limit of the large marsh or lake to detect change in agricultural practices. Whereas the data from the edge of the marsh suggest that cereal cultivation was present since the Late Neolithic and olives since the Early Bronze Age, the regional pollen records at Tenaghi-Philippon indicate the first really clear anthropogenic signal associated with a continuous Olea pollen curve since $1900 \mathrm{cal}$ BC during the Middle Bronze Age (Greig and Turner, 1974). This lag-time of around 1400 years for recording agricultural practices in local and regional sinks confirms the importance of a multiscalar approach to identify the extent of the impact on vegetation cover (Glais et al., 2016a). The spatial resolution of the data is as important as the temporal resolution of the selected archives.

\subsection{Environmental changes from the Late Bronze Age to the Iron Age (ca. $1650-800 \mathrm{cal} B C$ )}

The cultural transition from the Middle to Late Bronze Age around $1650 \mathrm{cal}$ BC is a gradual one which is often difficult to recognize. Macedonia and Thrace belong to a large cultural area which comprises the southern part of the Balkans (Treuil et al., 2008). Contrary to what have been observed in the rest of the Aegean world (Treuil et al., 2008), the available archaeological data suggest less dense settlement than during the previous periods (Koukouli-Chryssantakhi et al., 2008) particularly in the lower part of the Philippi-Drama plain (e.g., Kalamonas, Sykia, Kourovo, Polystylo; Fig. 2). Concerning the vegetation composition at the edges of the Tenaghi-Philippon marsh, the Dik4 pollen record (LPAZ5) shows the decrease in alder $(<5 \%)$ concurrently with the increase in hydro-hygrophitic taxa and Poaceae ca. $1650 \mathrm{cal}$ BC, sounded the end of a continuous and relatively regular pace since the first intensive clearance ca. $4550 \mathrm{cal} \mathrm{BC}$. The definitive opening of alder and oak forest is observed ca. 1650-800 cal BC. These are replaced with hydro-hygrophytes and Poaceae for the marsh edges and to a lesser extent by Pinus sylvestris and xerothermophilous taxa, probably from the slopes.

The decrease in anthropogenic indicators (both anthropic-nitrophilous and anthropozoogenous taxa), cereals and coprophilous NPPs on the Dik4 core (LPAZ5; Fig. 9) during the Late Bronze Age (ca. 1650-1000 cal BC) and the Iron Age (ca. 1000-800 cal BC), is probably due to a decrease in the settlement, but also to a change in the overall settlement pattern. In fact, during the Middle and Late Bronze Age, the few archaeological sites, which are often defensive, are located on the piedmont, like Dikili Tash, and on the lower slopes of the surrounding mountains (Fig. 2). The shift of agricultural practices towards the apical parts of the alluvial fans and a decline of human impact on the wetlands may be deduced. However, the highest magnitude of the sedimentary charcoal influx values at Dik4 occurs at this moment, in total CHAR but also in large charcoal-type fire episodes (Figs. 5-9), indicates intensifying anthropogenically induced fire regimes of local origin, recorded from 1650 to $800 \mathrm{cal} \mathrm{BC}$. This could be explained by the use of fire to clear shrublands along the wetland edges and on the apical part of the alluvial fans and the mountain slopes to create pastureland closer to settlement sites (Lespez, 2008; Marinova et al., 2012).

The xerothermophilous taxa show a peak values ca. 1300-1000 cal BC at Dik4 (Fig. 9), confirming the data from the Tenaghi-Philippon pollen record of Greig and Turner (1974) 
which shows an increase in maquis vegetation at this time. This indicates a drier period from the North-Atlantic to the Mediterranean areas also evidenced by marine core pollen records (Fletcher and Zielhofer, 2013). There is a general consensus that the time period between 1450 and $850 \mathrm{cal} \mathrm{BC}$ was one of the drier periods of the Holocene with generally harsher conditions (Finné et al., 2011) punctuated by drier events such as the so-called "1200 cal BC event" (Kaniewski et al., 2013). Nevertheless, this period in Dik4 sequence also shows the maximum percentage of eu-mesotrophic NPPs, high levels of hydro-hygrophytes taxa, the rise of Poaceae and a peak of LOI (Fig. 6), all of which indicate an increase of the water level in the marsh and the development of wetlands. The explanation of this opposite hydrological pattern may have been a consequence of both the "Mediterraneanization" of the climate in the Aegean area after 2500 cal BC that resulted in intensification in winterseason precipitation and summer aridity (Kuhnt et al., 2008) and the complexity of the environmental changes. Indeed, during the $2^{\text {nd }}$ millennium cal $B C$, human modification of land cover became an increasingly significant factor in landscape change (Marinova et al., 2012; Weiberg et al., 2016). This coincides also with an increase trend in the sedimentation accumulation rate in the small Dikili Tash valley (Fig. 5), spanning around a millennium until 900-800 cal BC. It also corresponds to the first detritic deposits observed on the plain in the large Xeropotamos alluvial fan (Lespez, 2003; Glais et al., 2016b). The extension of the cultivated and grazing areas the upper parts of the fans and the lower slopes is responsible for the first phase of erosion and could explain the development of xerothermophilous species such as olive tree, which is favored by the erosion of soil profiles. The drier climate and intensification of human impact combined to create typical heliophilous and sclerophyllous vegetation ecosystems during the Late Bronze Age as in many other areas of the Mediterranean (Roberts et al., 2011). Further, the driest conditions of the period underwent typical Mediterranean flood flows that transported silt and sand from soil erosion on the piedmont and mountain slopes. The increase of sedimentation input in the wetland could have caused the abandonment of the lowland, regularly flooded when the water level remained high during part of the year due to the increase in fall-winter precipitation and the absence of hydraulic control on the edge of the marsh.

With the beginning of the Iron Age ca. 1000 cal BC, evidence for agricultural and livestock activities has been recovered, coinciding with the reappearance of cereal pollen grains and rising patterns in anthropic-nitrophilous taxa, coprophilous NPPs, perennial pasture plants and anthropozoogenous taxa in the Dik4 pollen record (bottom of LPAZ6; Fig. 9). The relatively low level of Cerealia type recorded in Dik4 in comparison with some of the previous periods is explained by the location of cultivated fields, probably located more on the alluvial fans than on the wetland edges whereas the increase in indicators of pastoral activities indicates that the edge of the marsh was again used for cattle and sheep breeding.

\subsection{Intensive agricultural practices and shaping Mediterranean cultivated landscapes during the late Iron Age and the Antiquity periods (ca. $800 \mathrm{cal} B C$-cal AD 300)}

On the Philippi-Drama plain, alder forest has almost disappeared (1-2\%) during Antiquity from the Dik4 sequence (Fig. 9). The percentage of arboreal pollen (10-23\%) is due to the presence of Pinus sylvestris at higher altitudes. Nevertheless, the data obtained from the Lower Strymon valley show that mixed oak forests were still developed on the middle slopes of the main mountain massif (Lespez et al., 2014; 2016). Although data for the Thracian period in the region (ca 900-600 cal BC) are quite limited due to the very few archaeological 
excavations for this period in Northern Greece (Koukouli-Chryssanthaki, 1998), the settlement pattern can be deduced from the study of settlement during the Greek (ca. 600$357 \mathrm{cal} \mathrm{BC}$ ), the Macedonian (357-148 cal BC) and the Roman (148 cal BC- cal AD 395) periods. The local Thracian tribes which had settled along the Struma River (Southwestern Bulgaria) had moved higher up into the surrounding mountains (Bozhkova et al., 2002; Lazarova et al., 2015). Evidence of agriculture is also confirmed from the Vaxevo settlement in southwestern Bulgaria which has several storage features for cultivated cereals (Popova, 2001). More generally, the Thracian period of occupation witnessed further development of agriculture, vine-growing, stock-breeding and ore-mining. The forests served as an important source of wood used for construction purposes, heating and metallurgy (Lazarova et al., 2015). In the local environment of Dik4 core, cereal pollen grains and coprophilous NPPs are still present even with very low percentages ca. 800-600 cal BC, probably indicating less pressure on agricultural and livestock activities closed to the marsh.

The Greek and Macedonian conquest of the Philippi-Drama plain which led to the foundation of the town of Philippi in $357 \mathrm{BC}$ is characterized in the Dik4 pollen record by a considerable rise in anthropic-nitrophilous, perennial pasture plants and coprophilous NPPs (Fig. 9). The first three culminate with maximum values through the entire pollen record during the Hellenistic period and for the first time offer an indication of land use intensification on the edge of the marsh. This corresponds primarily to herding practices which were probably favored by the progressive silting of the edge of the marsh since the Bronze Age, clearly recorded on the Dik4 core and on the Xeropotamos alluvial fan (Lespez, 2003; Glais et al., 2016b). These observations may be linked with the account by Theophrastus in which he described increased land use of the wetland during this period, with drainage and farming improvement. This account was difficult to interpret prior to these recent investigations without sedimentological and palynological records (Lespez and Tirologos, 2004). Toponymic studies show that many Roman vici (rural settlements) were established on earlier Thracian villages (Papazoglou, 1988; Koukouli-Chryssanthaki, 1998): of the 37 known for the Roman period, at least 16 were inhabited during the Iron Age. From this settlement pattern, we can deduce that agricultural practices were developed in different landscape contexts, on the eroded luvisol of alluvial fans, but also on the heavy and organic soils of the edge of the Tenaghi-Philippon marsh (Lespez et al., 2000; Lespez, 2003; Glais et al., 2016b). Alluvial fans were mainly exploited for cereals that may have alternated with pulses and fallow land (Lespez 2008). The data obtained from the rare excavated archaeological sites show a strong development of sheep breeding (Koukouli-Chryssanthaki, 1998; Lespez, 2008). During the Roman period, archaeological and historical data demonstrate that the plain was entirely settled (Lespez, 2008). The last biomass burning phase documented by this record covers only two centuries (ca. 100 cal BC-cal AD 100) and suggests fire activity in the surroundings related to both agriculture and grazing activities while the highest level of coprophilous NPPs suggests that the wetland was intensively used for herding. Another explanation of this short and intensive peak would correspond to the famous Philippi battle occurred in September/October 42 cal BC, when tens thousands of soldiers and cavalrymen confront each other in this region (Collart, 1929). The observations of intensification of human impact since roman period are all quite similar to those made in the Lailias Mountains (70 km) to the north (Gerasimidis, 2000) and suggest a completely humanly modified landscape on the plain, the edge of the wetland and the mountain slopes.

\section{Conclusions}


The study of the Dik4 core highlights the necessity to combine off-site palynological evidence and on-site palaeobiological data to assess the effects of specific farming and herding practices on vegetation cover from the Late Neolithic on. It remains difficult to identify cultivated or harvested plant species from pollen taxa recovered. However, palynological analysis associated with the seed/fruit record, such as that conducted at Dikili Tash, offers a strong signal for harvesting, herding and fruit gathering, including the presence of plants that produce low amounts of pollen. The combined results obtained in this study clarify the spatial pattern of changes in vegetation cover at the edge of the Tenaghi-Philippon marsh in an area that was soon cultivated. In contradiction to the first studies based on the Tenaghi-Philippon marsh deposits, the onset of anthropogenic disturbance was much earlier than $2500 \mathrm{cal} \mathrm{BC}$. Access to a permanent water source and a range of nearby areas suitable for agropastoral activities, hunting, fishing and collecting, made the site of Dikili Tash attractive for the long-term establishment of farmers, who even resettled at the site after the abandonment period. The presence of four main vegetation formations since the Late Neolithic can be argued: riparian vegetation, oak woodlands, open vegetation in the form of wooded grassland and cultivated fields.

The study reveals two phases of decline in land use directly on the edge of the marsh, although indicators of anthropogenic disturbance of the vegetation never entirely disappear: between 3900-3300 cal BC at the transition from the Late Neolithic (LNII) to the Bronze Age and from 1650-800 cal BC with a reorganization of the settlement on the higher slopes. In any of these periods, climate changes can be directly evoked for decline in human impact even if local changes in geographic conditions, such as a rise in the water table, can be invoked to explain diminishing local land use as also observed in the Lower Strymon valley. In contrast, four periods are characterized by an increase in land use extension and intensification: Late Neolithic (4500-3900 cal BC); Early to Middle Bronze Age (3000-1600 cal $\mathrm{BC})$, the Iron Age (1000-800 cal BC) and Antiquity during the Macedonian (ca. 357-148 cal $B C$ ) and Roman periods (148 cal BC - cal AD 395). Except for the Iron Age, these correspond to well-known archaeological periods and the observed anthropogenic changes are correlated with settlement expansion. During the Late Neolithic, it is probable that development of agriculture did not cause complete alteration of woodlands and landscape structure, but rather stability of a mosaic of vegetation forms. This would indicate balanced exploitation, repeated use of limited patches of land close to the settlement, perhaps involving efforts at conservation of subsistence resources and renewal of their productive potential. From the Early Bronze Age on, landscape changes are progressive and lasting. Thus, the agricultural landscape in Northeastern Greece was largely established before Antiquity, as often proposed by historical research focused on the consequences of Greek colonization. Intensification of agricultural activities clearly appears during the Iron Age and the role of the Thracian population in the shaping of the agricultural landscapes of Northern Greece remains to be better explained by on-site and off-site palaeoenvironmental research.

More generally, this case study highlights the necessity of using palaeoecological data in multiscalar approaches, from archeological site to regional sink, by combining them with other indicators to determine the dynamics of mosaic landscapes in Northern Aegean areas. It is essential to assess the role of the change of agricultural practices (herding, farming, burning) in the landscape shaping and more generally to discuss the question of human society-environment-climate interactions that do not always have the same periodicities. 


\section{Acknowledgments}

This study is part of the framework of the international PaleoMex-INEE Research Program, itself a component of the Mediterranean Integrated Studies at Regional and Local Scales [MISTRALS] support by the INEE and INSU of the CNRS. Funding for the present study was also obtained from the RELICTFLORA (P11RNM-7033) project, provided by the Junta de Andalucía (Spain). J.A. López-Sáez is currently supported by a research grant (Spanish Ministry of Education, Culture and Sport) at Caen Normandy University and Boris Vannière is supported by the Région Franche-Comté (project GDRI HETSE - RECH-EXCEL). We express our gratitude to all of the institutions that support, directly or indirectly, the research carried out at and around Dikili Tash, in particular the Archaeological Society, the French School at Athens, the French Ministry of Foreign and European Affairs and the Institute of Aegean Prehistory (INSTAP). For their assistance, we also thank the heads of the Ephorate of Prehistoric and Classical Antiquities of Kavala (Ministry of Culture, Greece). Special thanks to Zoï Tsirtsoni for her comments on the archaeological data, Francisca Alba-Sánchez for their age-model advice and collaboration and Rebecca Miller for revising the original manuscript. Finally, this manuscript benefited from the stimulating comments of two anonymous reviewers.

\section{References}

Atherden, M. A., Hall, J. A., Dunn, A., 2000. Palynological Evidence from the Strymon Delta, Macedonia, Greece. People as an agent of environmental change, 16, 2.

Behre, K. E., 1981. The interpretation of anthropogenic indicators in pollen diagrams. Pollen et spores, 23(2), 225-245.

Berger, J.-F., Guilaine, J., 2009. The 8200 cal BP abrupt environmental change and the Neolithic transition: A Mediterranean perspective. Quaternary International 200, 31-49.

Berger, J.-F., Lespez, L., Glais, A., Kuzucuoğlu, C., Hourani, F., Barra, A., Guilaine, J., 2016. Interactions between climate change and human activities during the Early to MidHolocene in the East Mediterranean basins (Greece, Turkey, Cyprus), Climate of the Past 12(9), 1847-1877, http://www.clim-past.net/12/1847/2016/

Blaauw, M., 2010. Methods and code for "classical" age-modelling of radiocarbon sequences. Quaternary Geochronology 5, 512-518.

Bintliff, J. L., 1977. Natural Environment and Human Settlement in Prehistoric Greece. Part I.

Bökönyi, S., 1986. Faunal remains. Excavations at Silagroi: A prehistoric Village in Northeast Greece, 1, 63-132.

Bottema, S., 1974. Late Quaternary vegetation history of northwestern Greece. Thesis, Groningen.

Bottema, S., 1980. On the history of the walnut (Juglans regia L.) in southeastern Europe. Acta Botanica Neerlandica, 29(5/6), 343-349.

Bottema, S., 1982. Palynological investigations in Greece with special reference to pollen as an indicator of human activity. Palaeohistoria 24, 257-289.

Bottema, S., Woldring, H., 1990. Anthropogenic indicators in the pollen record 19 of the Eastern Mediterranean. In Man's Role in the Shaping of the Eastern Mediterranean Landscape: Proceedings of the Symposium on the Impact of Ancient Man on the Landscape of the E Med Region \& the Near East: Groningen, March 1989 (p. 231). CRC Press. 
Boyer, P., Roberts, N., Baird, D., 2006. Holocene environment and settlement on the Çarşamba alluvial fan, south-central Turkey: Integrating geoarchaeology and archaeological field survey. Geoarchaeology, 21(7), 675-698.

Bozkova, A., Delev, P., Alexandrov, S., Vulcheva, D., 2002. Koprivlen: A Thracian Settlement on the Middle Nestos. Fol, A.(Ed.), 469-484.

Brown, A.G., Hawkins, C., Ryder, L., Hawken, S., Griffith, F., Hatton, J., 2014. Palaeoecological, archaeological and historical data and the making of Devon landscapes. I. The Blackdown Hills. Boreas, 43(4), 834-855.

Budd, C., Lillie, M., Alpaslan-Roodenberg, S., Karul, N., Pinhasi, R., 2013. Stable isotope analysis of Neolithic and Chalcolithic populations from Aktopraklık, northern Anatolia. Journal of Archaeological Science, 40(2), 860-867.

Cappers, R.T.J., 2008. Plant remains from the Late Neolithic and Early Chalcolithic levels. In J. Roodenberg \& S. Alpaslan Roodenberg (Eds.), Life and death in a Prehistoric settlement in northwest Anatolia: The Ilipinar excavations. vol. 3, 117-148. Leiden: Nederlands Instituut voor het Nabije Oosten.

Carpenter, R., 1966. Discontinuity in Greek civilization. Cambridge UP, 80 p.

Collart, P., 1929. Note sur les mouvements de troupes qui ont précédé la bataille de Philippes, Bulletin de Correspondance Hellénique LIII, 351-364

Connor, S.E., Ross, S.A., Sobotkova, A., Herries, A.I., Mooney, S.D., Longford, C., Iliev, I., 2013. Environmental conditions in the SE Balkans since the Last Glacial Maximum and their influence on the spread of agriculture into Europe. Quaternary Science Reviews, 68, 200215.

Cugny, C., Mazier, F., Galop, D., 2010. Modern and fossil non-pollen palynomorphs from the Basque mountains (western Pyrenees, France): the use of coprophilous fungi to reconstruct pastoral activity. Vegetation history and Archaeobotany, 19(5-6), 391-408.

Darcque, P., 2013. Dikili Tash, un village néolithique dans le Nord de la Grèce. Comptes Rendus de l'Académie des Inscriptions et Belles-Lettres, 51-73.

Darcque, P., Tsirtsoni, Z., 2010. Evidence from Dikili Tash (Eastern Macedonia, Greece) and the tell issue. In: S. Hansen (ed.) [Leben auf dem Tell als soziale Praxis, Beiträge des nternationalen Symposiums, 2007 Feb 26-27, Berlin, Germany]. [Proc.in German]. Rudolf Habelt., Bonn, pp 55-69.

Darcque, P., Koukouli-Chryssanthaki, Ch., Malamidou, D., Tsirtsoni, Z., 2009. Dikili Tash, Bulletin de Correspondance Hellénique 133, 529-541.

Darcque, P., Koukouli-Chryssanthaki, Ch., Malamidou, D., Tsirtsoni, Z., Lespez, L., GermainVallée, C., 2014. The impact of environmental changes on the Neolithic settlement of Dikili Tash (Northern Greece). Physis

Dean Jr, W.E., 1974. Determination of carbonate and organic matter in calcareous sediments and sedimentary rocks by loss on ignition: comparison with other methods. Journal of Sedimentary Research, 44(1), 242-248.

De Cupere, B., Frémondeau, D., Kaptijn, E., Marinova, E., Poblome, J., Vandam, R., Van Neer, W., 2017. Subsistence economy and land use strategies in the Burdur province (SW Anatolia) from prehistory to the Byzantine period, Quaternary International (436), Part B, 4-17.

Digerfeldt, G., Olsson, S., Sandgren, P., 2000. Reconstruction of lake-level changes in lake Xinias, central Greece, during the last 40000 years. Palaeogeography, Palaeoclimatology, Palaeoecology, 158(1), 65-82. 
Enache, M.D., Cumming, B.F., 2006. Tracking recorded fires using charcoal morphology from the sedimentary sequence of Prosser Lake, British Columbia (Canada). Quaternary Research, 65(2), 282-292.

Enache, M.D., Cumming, B.F., 2007. Charcoal morphotypes in lake sediments from British Columbia (Canada): an assessment of their utility for the reconstruction of past fire and precipitation. Journal of Paleolimnology, 38(3), 347-363.

Faegri, K., Iversen, J., 1989. Textbook of Pollen Analysis. John Wiley \& Sons, Chichester.

Filipovitch, L., 1977. Palynological data for the Postglacial distribution of Juglans in the composition of the Bulgarian flora. Phytology, 6, 32-37.

Filipović, D., Challinor, D., Andrič, M., 2014. Vinča tell in southeast Europe: Multi-proxy palaeobotanical evidence from Late Neolithic levels and the implications for the environment and economy. Quaternary International.

Fletcher, W.J., Zielhofer, C., 2013. Fragility of Western Mediterranean landscapes during Holocene rapid climate changes. Catena, 103, 16-29.

Florenzano, A., Torri, P., Rattighieri, E., Massamba, N..,Siala, I., Mercuri, A.M., 2012. Cichorioideae-Cichoriaceae as pastureland indicator in pollen spectra from southern Italy. Atti del CongressoA. I. Ar, pp. 342-353.

Fouache, E., Pavlopoulos, K., 2011. The interplay between environment and people from Neolithic to Classical times in Greece and Albania. In Landscapes and Societies, Springer, Netherlands, 155-166.

Geramisidis, A., 2000. Palynological evidence for human influence on the vegetation of Moutain Regions in Northern Greece: The case of Lailias, Serres. In Halstead, P. (eds), Landscape and Land Use in Postglacial Greece. Sheffield Studies in Aegean Archaeology, Sheffield, 28-37.

Ghilardi, M., Kunesch, S., Styllas, M., Fouache E., 2008. Reconstruction of Mid-Holocene sedimentary environments in the central part of the Thessaloniki Plain (Greece), based on microfaunal identification, magnetic susceptibility and grain-size analyses, Geomorphology, 97, (3-4), 617-630.

Ghilardi, M., Psomiadis, D., Cordier, S., Delanghe-Sabatier, D., Demory, F., Hamidi, F., Paraschou, T., Dotsika, E., Fouache, E., 2012. The impact of rapid early-to mid-Holocene palaeoenvironmental changes on Neolithic settlement at Nea Nikomideia, Thessaloniki Plain, Greece. Quaternary International, 266, 47-61.

Gkouma, M., Karkanas, P., 2016. The physical environment in Northern Greece at the advent of the Neolithic, Quaternary International, 1-10

Glais, A., López Sáez, J.A., Lespez, L., Davidson, R., 2016a. Climate and human environment relationships on the edge of the Tenaghi-Philippon marsh (Northern Greece) during the Neolithization process, Quaternary International 403, pp. 237-250.

Glais, A., Lespez, L., Davidson, R., López Sáez, J.A., Birée, L., 2016b. 3000 ans de détritisme en Grèce du Nord : entre fluctuations climatiques et anthropisation des zones humides. Geomorphologie, reliefs, processus, environnement 22(2), 187-208.

Greig, J.R.A., Turner, J., 1974. Some Pollen Diagrams from Greece and their Archaeological Significance. Journal of Archaeological Science 1, 177-194.

Grimm, E.C., 1987. CONISS: a Fortran 77 Program for stratigraphically constrained cluster analysis by the method of incremental sum of squares. Computers and Geosciences 13, 13-35.

Grimm, E.C., 1992. Tilia Version 2. Illinois State Museum. Research and Collection Center, Springfield, IL 62703. USA. 
Grimm, E.C. 2004. Tilia graph v. 2.0. 2. Illinois State museum, Research and Collections Center, Springfield, IL 62703. USA.

Groenhuijzen, M.R., Kluiving, S.J., Gerritsen, F.A., Künzel, M., 2015. Geoarchaeological research at Barcın Höyük: Implications for the initial Neolithic occupation of northwest Anatolia. Quaternary International 359-360, 452-461.

Groves, C. R., Game, E. T., Anderson, M. G., Cross, M., Enquist, C., Ferdana, Z., Evan Girvetz, Gondor, A., Hall, K.R., Higgins, J., Marshall, R., Popper, K., Schill, S., Shafer S.L., 2012. Incorporating climate change into systematic conservation planning. Biodiversity and Conservation, 21(7), 1651-1671.

Halstead, P., 2000. Land use in postglacial Greece: cultural causes and environmental effects. In Halstead, P. (eds), Landscape and Land Use in Postglacial Greece. Sheffield Studies in Aegean Archaeology, Sheffield, 110-128.

Helmer, D., 1997. Faune sauvage et domestique. Dossiers d'Archéologie, 222, 40-41.

Hodder, I., 1990. The domestication of Europe. B. Blackwell, Incorporated.

Izdebski, A., Holmgren, K., Weiberg, E., Stocker, S.R., Büntgen, U., Florenzano, A., Gogou, A., Leroy, S.A.G., Luterbacher, J., Martrat, B., Sicre, A.A., Triantaphyllou, M., Xoplaki, E., 2016. Realising consilience: How better communication between archaeologists, historians and natural scientists can transform the study of past climate change in the Mediterranean, Quaternary Science Reviews 136, 5-22.

Jones, G., Valamoti, S.M., 2005. Lallemantia, an imported or introduced oil plant in Bronze Age northern Greece. Vegetation history and archaeobotany, 14(4), 571-577.

Jullien, R., 1992. Les faunes domestique et sauvage, les moyens de subsistence. BCH suppl. XXIV, 147-153.

Kaniewski, D., Van Campo, E., Guiot, J., Le Burel, S., Otto, T., Baeteman, C., 2013. Environmental roots of the Late Bronze Age crisis. PLoS One, 8(8), e71004.

Karkanas, P, Pavlopoulos, K, Kouli, K, Ntinou, M, Tsartsidou, G, Facorellis, Y, Tsourou, T., 2011. Paleoenvironment and site formation processes of the Neolithic lakeside site of Dispilio, Kastoria, northern Greece. Geoarchaeology 26, 83-117.

Knithakis, M., 1983. Inventory of Karstic Spring of Greece, Hydrological Basin of Strimonas River. IGME: Hydrological and Hydrogeological Investigations 28/4, $52 \mathrm{p}$.

Kołaczek, P., Zubek, S., Błaszkowski, J., Mleczko, P., Margielewski, W., 2013. Erosion or plant succession-How to interpret the presence of arbuscular mycorrhizal fungi (Glomeromycota) spores in pollen profiles collected from mires. Review of Palaeobotany and Palynology, 189, 29-37.

Kotthoff, U., Müller, U.C., Pross, J., Schmiedl, G., Lawson, I.T., van de Schootbrugge, B., Schulz, H., 2008. Lateglacial and Holocene vegetation dynamics in the Aegean region: an integrated view based on pollen data from marine and terrestrial archives. The Holocene 18 (7), 1019-1032.

Kotthoff, U., Koutsodendris, A., Pross, J., Schmiedl, G., Bornemann, A., Kaul, C., Marino, G., Peyron, O., Schiebel, R., 2011. Impact of Lateglacial cold events on the northern Aegean region reconstructed from marine and terrestrial proxy data. Journal of Quaternary Science 26, 86-96.

Koukouli-Chryssanthaki, H., 1998. Drama and its region from the Neolithic to the end of the Roman period, in Drama and its Region symposium, History and politics, (in greek), 33-68.

Koukouli-Chryssanthaki, H., Treuil, R., 2008. Dikili Tash, village préhistorique de Macédoine orientale. Recherches franco-helléniques dirigées par la Société archéologique d'Athènes 
et l'école francaise d'Athènes (1986-2001), Bibliothèque de la Société archéologique $d^{\prime}$ Athènes 254. Athens: Société archéologique d'Athènes.

Koukouli-Chryssanthaki, H., Malamidou, M., Lespez, L. 2008. Carte archéologique de la plaine de Philippes-Drama. In: Koukouli-Chryssanthaki, H., Treuil, R., (eds), Dikili Tash, village préhistorique de Macédoine orientale. Recherches franco-helléniques dirigées par la Société archéologique d'Athènes et l'école francaise d'Athènes (1986-2001), Bibliothèque de la Société archéologique d'Athènes 254. Athens: Société archéologique d'Athènes, 395-414.

Kouli, K., 2012. Vegetation development and human activities in Attiki (SE Greece) during the last 5000 years, Vegetation History and Archaeobotany 21, 267-278.

Kouli, K., 2015. Plant landscape and land use at the Neolithic lake settlement of Dispilió (Macedonia, northern Greece). Plant Biosystems, 149, 195-204.

Kouli, K., Dermitzakis, M.D., 2008. Natural and cultural landscape of the Neolithic settlement of Dispilio: palynological results. Hellenic Journal of Geosciences 43, 29-39.

Krahtopoulou, A., 2000. Holocene alluvial history of Northern Pieria, Macedonia, Greece. In Halstead, P., Frederick, C. (eds), Landscape and land use in postglacial Greece, Sheffield Studies in Aegean Archaeology 3, Sheffield Academic Press, Sheffield, 15-27.

Kuhnt, T., Schmiedl, G., Ehrmann, W., Hamann, Y., Andersen, N., 2008. Stable isotopic composition of Holocene benthic foraminifers from the Eastern Mediterranean Sea: past changes in productivity and deep water oxygenation. Palaeogeography, Palaeoclimatology, Palaeoecology, 268(1), 106-115.

Lawson, I., Frogley, M., Bryant, C., Preece, R., Tzedakis, P., 2004. The Lateglacial and Holocene environmental history of the Ioannina basin, north-west Greece. Quaternary Science Reviews 23, 1599-1625.

Lazarova, M., Marinova, E., Tonkov, S., Snowball, I., 2015. A 5000-year pollen and plant macrofossil record from the Osogovo Mountain, Southwestern Bulgaria: Vegetation history and human impact. Review of Palaeobotany and Palynology, 223, 1-9.

Lespez, L., 2003. Geomorphic responses to long-term land use changes in Eastern Macedonia (Greece). Catena, 51, 181-208.

Lespez, L., 2007. Les dynamiques des systèmes fluviaux en Grèce du Nord au cours des 7 derniers millénaires : vers une approche multi-scalaire des interactions Nature/Société. Géomorphologie, relief, processus, environnement, 1, 49-66.

Lespez, L., 2008. L'environnement du Néolithique à l'Âge du Bronze. In Treuil R., Darcque P., Poursat J.-C., Touchais G. (Eds), Les civilisations égéennes du Néolithique à l'Âge du Bronze, PUF, Nouvelle Clio (2e ed.), Paris, 13-30.

Lespez, L., 2011. Territoires protohistoriques en Grèce du Nord, approche géographique et geoarchéologique. In Treuil, R., Kourtessi-Philippakis, G. (dir.), Archéologie du territoire, de l'Egée au Sahara, Presses Universitaires de la Sorbonne, 95-109.

Lespez, L., 2014. Les recherches géoarchéologiques et le cadre géographique de la cité antique de Philippes. In Sève, M. (ed) : Philippes 1914-2014: 100 ans de recherches de l'École française d'Athènes, Ecole Française d'Athènes, $8 \mathrm{p}$.

Lespez, L., Dalongeville, R., 1998. Morphogenèse würmienne en Grèce du Nord: le piémont des montagnes de Lékani. Géomorphologie, Relief, Processus, Environnement 4, 331-350.

Lespez, L., Dalongeville, R., Noirel-Schutz, C., Suc, J.-P., Koukouli-Chryssanthaki, H., Treuil, R., 2000. Les paléoenvironnements du site préhistorique de Dikili Tash (Macédoine orientale, Grèce), Bulletin de Correspondance Hellénique 124, 413-434. 
Lespez, L., Malamidou, D., Tsirtsoni, Z., Yiouni, P., 2001. La production des poteries néolithiques à décor peint "noir sur rouge" en Grèce du Nord. Bulletin de correspondance hellénique, 125, 630-632.

Lespez, L., Tirologos G., 2004. Changements climatiques, transformations des paysages et sources anciennes: l'exemple du témoignage de Théophraste à propos de Philippes (Grèce). In O Cantat et J.-O. Gires (dir.), Actes du XVIle colloque international de Climatologie: Climat, "Mémoires du temps", Caen, 8-10 Septembre 2004, 59-62.

Lespez, L., Tsirtsoni, Z., Darcque, P., Koukouli-Chryssanthraki, H., Malamidou, D., Treuil, R., Oberlin, C. 2013. The lowest levels at Dikili Tash, northern Greece: a missing link in the Early Neolithic of Europe. Antiquity 87, 30-45.

Lespez, L., Tsirtsoni, Z., López-Sáez, J.-A., Le Drezen, Y., Glais, A, 2014. Beyond determinism: For a local approach to nature/society interactions in the southern Balkans at the transition from the Neolithic to the Bronze Age. In: Arnaud-Fassetta, G., Carcaud, N. (Eds.), French Geoarchaeology in the 21st 964 cenutury, Editions du CNRS, Paris, 157-171. Lespez, L., Glais, A., López-Sáez, J.-A., Le Drezen, Y., Tsirtsoni, Z., Davidson, R., Birée, L., Malamidou, D., 2016. Mid-Holocene rapid environmental changes and human adaptation in Northern Greece. Quaternary Research 85, 2, 227-244. Lespez, L., Tsirtsoni, Z., Darcque, P.., Malamidou, D., Koukouli-Chryssanthaki, H., Glais, A., 2016. Identifying the earliest Neolithic settlements in the South-Eastern Balkans: methodological considerations based on the recent geoarchaeological investigations at Dikili Tash (Greek Eastern Macedonia). In Reingruber, A., Tsirtsoni, Z., Nedelcheva, P., (eds), Going West. The Dissemination of Neolithic Innovations between the Bosporus and the Carpathians, Themes in Contemporary Archaeology, Routledge, Oxon and New-York, pp. 43-56.

Long, C.J., Whitlock, C., Bartlein, P.J., Millspaugh, S.H., 1998. A 9000-year fire history from the Oregon Coast Range, based on a high-resolution charcoal study. Canadian Journal of Forest Research, 28(5), 774-787.

López-Merino, L., López-Sáez, J. A., Alba-Sánchez, F., Pérez-Díaz, S., Carrión, J. S., 2009. 2000 years of pastoralism and fire shaping high-altitude vegetation of Sierra de Gredos in central Spain. Review of Palaeobotany and Palynology, 158(1), 42-51.López-Sáez, J.A., López-Merino, L., 2005. Precisiones metodológicas acerca de los indicios paleopalinológicos de agricultura en la Prehistoria de la Península Ibérica.

López-Sáez, J.A., López-Merino, L., 2007. Coprophilous fungi as a source of information of anthropic activities during the Prehistory in the Amblés Valley (Avila, Spain): the archaeopalynological record. Revista Española de Micropaleontologa 39, 103-116.

López-Sáez, J.A., van Geel, B., Martín-Sánchez, M., 2000. Aplicación de los microfósiles no polínicos en Palinología Arqueológica. In: Oliveira-Jorge, V. (Ed.), Contributos das Ciências e das Technologias para a Arqueologia da Península Ibérica. Actas $3^{\circ}$ Congresso de Arqueologia Peninsular, vol. IX. Vila-Real, Portugal, setembro de 1999, Adecap, Porto, 1120.

López-Sáez, J.A., López, P., Burjachs, F., 2003. Arqueopalinología: Síntesis Crítica. Polen 12, 5-35.

Magny, M., Combourieu Nebout, N., de Beaulieu, J.L., Bout-Roumazeilles, V., Colombaroli, D., Desprat, S., Francke, A., Joannin, S., Peyron, O., Revel, M., Sadori, L., Siani, G., Sicre2, S. Samartin, M.A., Simonneau, A., Tinner, W., Vannière, B., Wagner, B., Zanchetta, G., Anselmetti, F., Brugiapaglia, E., Chapron, E., Debret, M., Desmet, M., Didier, J., Essallami, L., Galop, D., Gilli, A., Haas, J.N., Kallel, N., Millet, L., Stock, A., Turon, J.L., Wirth, S., 2013. 
North-south palaeohydrological contrasts in the central Mediterranean during the Holocene: tentative synthesis and working hypotheses. Climate of the Past 9, 2043-2071.

Mangafa, M., Kotsakis, K., 1996. A new method for the identification of wild and cultivated charred grape seeds. Journal of Archaeological Science, 23(3), 409-418.

Marinova, E., 2009. Plant economy and vegetation during the Early Neolithic of Bulgaria. In Ivan Gatsov and Yavor Boyadzhiev (eds.) 2009 The First Neolithic Sites in Central/SouthEast European Transect Volume I: Early Neolithic Sites on the Territory of Bulgaria. BAR International S2048, 59-62.

Marinova, E., Tonkov, S., Bozilova, E., Vajsov, I., 2012. Holocene anthropogenic landscapes in the Balkans: the palaeobotanical evidence from southwestern Bulgaria. Vegetation history and archaeobotany, 21(4-5), 413-427.

Marinova, E., Valamoti, S.M., 2014. Crop diversity and choices in the prehistory of SE Europe: the archaeobotanical evidence from Greece and Bulgaria. EARTH Monographs Book 1.

Marinova, E., Ntinou, M., 2017. Neolithic woodland management and land-use in southeastern Europe: The anthracological evidence from Northern Greece and Bulgaria. Quaternary International.

Marlon, J., Bartlein, P.J., Whitlock, C., 2006. Fire-fuel-climate linkages in the northwestern USA during the Holocene. The Holocene, 16(8), 1059-1071.

Mayewski, P.A., Rohling, E., Stager, C., Karlen, W., Maasch, K., Meeker, L.D., Meyerson, E., Gasse, F., vanKreveld, S., Holmgren, K., Lee-Thorp, J., Rosqvist, G., Rack, F., Staubwasser, M., Schneider, R., 2004. Holocene climate variability, Quaternary Research 62, 243-255.

Mercuri, A.M., Bandini Mazzanti, M., Florenzano, A., Montecchi, M.C., Rattighieri, E., Torri, P., 2013. Anthropogenic Pollen Indicators (API) from archaeological sites as local evidence of human-induced environments in the Italian peninsula. Annale Botanica 3, 143-153.

Moore, P.D., Webb, J.A., Collinson, M.E., 1991. Pollen Analysis, $2^{\text {nd }}$ edition. Blackwell Scientific Publications, London.

Müller, U., Pross, J., Tzedakis, P.C., Gamble, C., Kotthoff, U., Schmiedl, G., Wulf, S., Christanis, K., 2011. The role of climate in the spread of modern humans into Europe. Quaternary Science Review 30, 273-279.

Ntinou, M., 2002. Vegetation and human communities in prehistoric Greece. Saguntum: Papeles del Laboratorio de Arqueología de Valencia, (5), 91-103.

Ntinou, M., Badal, E., 2000. Local vegetation and charcoal analysis: an example from two late neolithic sites in Northern Greece. In Halstead P. \& Frederick C. (eds.), Landscape and land use in postglacial Greece. Sheffield. Sheffield Academic Press, 38-51.

Orton, D., 2012. Herding, settlement, and chronology in the Balkan Neolithic. European Journal of Archaeology, 15(1), 5-40.

Pagnoux, C., Bouby, L., Ivorra, S., Petit, C., Valamoti, S.M., Pastor, T., Picq, S., Terral, J.F., 2015. Inferring the agrobiodiversity of Vitis vinifera L.(grapevine) in ancient Greece by comparative shape analysis of archaeological and modern seeds. Vegetation History and Archaeobotany, 24(1), 75-84.

Papazoglou, F., 1988. Les villes de Macédoine à l'époque romaine (Vol. 16). Ecole française d'Athènes.

Pavlopoulos, K., Fouache, E., Sidiropoulou, M., Triantaphyllou, M., Vouvalidis, K., Syrides, G., Gonnet, A., Greco, E., 2013. Palaeoenvironmental evolution and sea-level changes in the coastal area of NE Lemnos Island (Greece) during the Holocene. Quaternary International $308,80-88$. 
Peyron, O., Goring, S., Dormoy, I., Kotthoff, U., Pross, J., de Beaulieu, J.L., DrescherSchneider, R., Vannière, B., Magny, M., 2011. Holocene seasonality changes in the central Mediterranean region reconstructed from the pollen sequences of Lake Accesa (Italy) and Tenaghi Philippon (Greece), The Holocene 21, 131-146.

Popova, T., 2001. Analysis of charred plant remains. In: Chohadžijev, S. (Ed.), Vaxevo Prehistorical Settlements. Faber, Veliko Turnovo (in Bulgarian with English summary), 3132.

Pross, J., Kotthoff, U., Müller, U.C., Peyron, O., Dormoy, I., Schmiedl, G., Kalaitzidis, S., Smith, A.M., 2009. Massive perturbation in terrestrial ecosystems of the Eastern Mediterranean region associated with the $8.2 \mathrm{kyr}$ B.P. climatic event. Geology 37, 887-890.

Pross, J., Koutsodendris, A., Christanis, K., Fischer, T., Fletcher, W.J., Hardiman, M., Kalaitzidis, S., Knipping, M., Kotthoff, U., Milner, A.M., Müller, U.C., Schmiedl, G., Siavalas, G., Tzedakis, P.C., Wulf, S., 2015. The 1.35-Ma-long terrestrial climate archive of Tenaghi Philippon, northeastern Greece: evolution, exploration and perspectives for future research. Newsletter Stratigraphy 48, 253-276.

Reille, M., 1992. Pollen et Spores d'Europe et d'Afrique du Nord. Laboratoire de Botanique Historique et Palynologie, Marseille, pp 543.

Reimer, P.J., Bard, E., Bayliss, A., Beck, J.W., Blackwell, P.G., Bronk Ramsey, C., Buck, C.E.,Cheng, H., Edwards, R.L., Friedrich, M., Grootes, P.M., Guilderson, T.P., Haflidason, H., Hajdas, I., Hatté, C., Heaton, T.J., Hoffmann, D.L., Hogg, A.G., Hughen, K.A., Kaiser, K.F., Kromer, B., Manning, S.W., Niu, M., Reimer, R.W., Richards, D.A., Scott, E.M., Southon, J.R., Staff, R.A., Turney, C.S.M., van der Plicht, J., 2013. IntCal13 and Marine13 radiocarbon age calibration curves 0-50,000 years cal BP. Radiocarbon 55 (4), 1869-1887.

Renfrew, C., Gimbutas, M., Elster, E. (eds), 1986. Excavation at Sitagroi: a prehistoric village in Northeast Greece, T.I. Los Angeles, University of California.

Rhodes, A.N., 1998. A method for the preparation and quantification of microscopic charcoal from terrestrial and lacustrine sediment cores. The Holocene, 8(1), 113-117.

Roberts, N., Eastwood, W.J., Kuzucuoğlu, C., Fiorentino, G., Caracuta, V., 2011. Climatic, vegetation and cultural change in the eastern Mediterranean during the mid-Holocene environmental transition. The Holocene, 21(1), 147-162. Sadori, L., Mercuri, A. M., Mariotti Lippi, M. 2010. Reconstructing past cultural landscape and human impact using pollen and plant macroremains. Plant Biosystems, 144, 940-951.

Schneider, S., Matthaei, A., Schlöffel, M., Meyer, C., Kronwald, M., Pint, A., Schütt, B., 2015. A geoarchaeological case study in the chora of Pergamon, western Turkey, to reconstruct the late Holocene landscape development and settlement history. Quaternary International, 367, 62-76.

Stock, F., Ehlers, L., Horejs, B., Knipping, M., Ladstätter, S., Seren, S., Brückner, H., 2015. Neolithic settlement sites in Western Turkey-palaeogeographic studies at Çukuriçi Höyük and Arvalya Höyük. Journal of Archaeological Science: Reports, 4, 565-577.

Stockmarr, J., 1971. Tablets with spores used in absolute pollen analysis. Pollen et Spores 13, 615-621.

Treuil, R. (éd.), 1992. Dikili Tash, village préhistorique de Macédoine orientale, I. Fouilles de Jean Deshayes (1961-1975), vol. 1, Bulletin de Correspondance Hellénique Supplément XXIV, Athènes.

Treuil, R., Darcque, P., Poursat, J.C., Touchais, G., (Eds.) 2008. Les civilisations égéennes du Néolithique et de l'Âge du Bronze, PUF, Paris. 
Triantaphyllou, M.V., Kouli, K., Tsourou, T., Koukousioura, O., Pavlopoulos, K., Dermitzakis, M.D., 2010. Paleoenvironmental changes since $3000 \mathrm{BC}$ in the coastal marsh of Vravron (Attica, SE Greece). Quaternary International, 216(1), 14-22.

Tsirtsoni, Z. (éd.), 2016. The Human Face of Radiocarbon: reassessing chronology in prehistoric Greece and Bulgaria, 5000-2000 cal BC, Travaux de la Maison de l'Orient et de la Méditerranée, Lyon, $520 \mathrm{p}$.

Turner, J., Greig, J.R.A., 1975. Some Holocene pollen diagrams from Greece. Review of Pallaeobotany and Palynology 20, 171-204.

Umbanhowar, C.E., Mcgrath, M.J., 1998. Experimental production and analysis of microscopic charcoal from wood, leaves and grasses. The Holocene, 8(3), 341-346.

Valamoti, S.M., 2004. Plants and people in Late Neolithic and Early Bronze Age northern Greece: an archaeobotanical investigation. British Archaeological Reports, Series 1258, Oxford.

Valamoti, S.M., Mangafa, M., Koukouli-Chryssanthaki, C., Malamidou, D., 2007. Grapepressings from northern Greece: the earliest wine in the Aegean? Antiquity, 81(311), 5461.

Valamoti, S.M., 2015. Harvesting the 'wild'? Exploring the context of fruit and nut exploitation at Neolithic Dikili Tash, with special reference to wine. Vegetation History and Archaeobotany, 24(1), 35-46.

van Andel, T.H., Runnels, C.N., 1987. Beyond the Acropolis: a rural Greek past. Stanford (CA), Stanford University Press.

van Andel, T.H., Zangger, E., 1990. Landscape stability and destabilisation in the prehistory of Greece. In Bottema, S. Entjes- Nieborg, G., Van Zeist, W. (Eds): Man's Role in the Shaping of the Eastern Mediterranean Landscape. Balkema, Rotterdam, 139-157.

van Andel, T.H., Zangger, E., Demitrack A., 1990. Land use and soil erosion in prehistoric and historical Greece. Journal of Field Archaeology, 17, 379-396.

van Geel, B., 2001. Non-pollen palynomorphs. In: Smol, J.P., Birks, H.J.B., Last WM (eds) Tracking environmental change using lake sediments, vol 3: Terrestrial, algal and silicaceous indicators. Kluwer, Dordrecht, pp. 99-119.

Vannière, B., Bossuet, G., Walter-Simonnet, A.V., Gauthier, E., Barral, P., Petit, C., Buatier, M., Daubigney, A., 2003. Land use change, soil erosion and alluvial dynamic in the lower Doubs Valley over the 1st millenium AD (Neublans, Jura, France). Journal of Archaeological Science, 30(10), 1283-1299.

Vannière, B., Colombaroli, D., Chapron, E., Leroux, A., Tinner,W., Magny, M., 2008. Climate versus human-driven fire regimes in Mediterranean landscapes: the Holocene record of Lago dell'Accesa (Tuscany, Italy). Quaternary Science Revue 27, 1181-1196.

Vannière, B., Power, M.J., Roberts, N., Tinner, W., Carrion, J., Magny, M., Bartlein, P., Colombaroli, D., Daniau, A.L., Finsinger, W., Gil-Romera, G., Kaltenrieder, P., Pini, R., Sadori, L., Turner, R., Valsecchi V., Vescovi, E., 2011. Circum-Mediterranean fire activity and climate changes during the mid-Holocene environmental transition (8500-2500 cal. BP). Holocene 21, 53-73.

Vannière, B., Blarquez, O., Rius, D., Doyen, E., Brücher, T., Colombaroli, D., Connor, S., Feurdean, A., Hickler, T., Kaltenrieder, P., Lemmen, C., Leys, B., Massa, C., Olofsson J., 2016. 7000-year human legacy of elevation-dependent European fire regimes. Quaternary Science Reviews, 132, 206-212.

Weiberg, E., Unkel, I., Kouli, K., Holmgren, K., Avramidis, P., Bonnier, A., Dibble F., Finn M., Izdebski A., Katrantsiotis C., Stocker, S.R., Andwinge M., Baika K., 2016. The socio- 
environmental history of the Peloponnese during the Holocene: Towards an integrated understanding of the past. Quarternary Science Reviews.

Weninger, B., Alram-Stern, E., Bauer, E., Clare, L., Danzeglocke, U., Jöris, C., Kubatzki, C., Rollefson, G., Todorova, H., Van Andel, T., 2006. Climate forcing due to the 8200 cal BP event observed at Early Neolithic sites in the eastern Mediterranean. Quaternary Research 66, 401-420.

Weninger, B., Clare, L., Rohling, E., Bar-Yosef, O., Böhner, U., Budja, M., Bundschuh, M., Feurdean, A., Gebel, H.G., Jöris, O., Linstädter, O., Mayewski, P.A., Mühlenbruch, T., Reingruber, A., Rollefson, G., Schyle, D., Thissen, D., Todorova, H., Zielhofer, C., 2009. The Impact of Rapid Climate Change on Prehistoric Societies during the Holocene in the Eastern Mediterranean. Documenta Praehistorica 36, 7-59.

Weninger, B., Clare, L., Gerritsen, F., Horejs, B., Krauß, R., Linstädter, J., Rohling, E.J., 2014. Neolithisation of the Aegean and Southeast Europe during the $6600-6000$ calBC period of Rapid Climate Change. Documenta Praehistorica 41, 1-31.

Wijmstra, T.A., 1969. Palynology of the first 30 metres of a $120 \mathrm{~m}$ deep section in northern Greece. Acta Botanica Neerlandica 18, 511-527.

Willis, K.J., 1994. The vegetational history of the Balkans. Quaternary Science Reviews 13, 769-788.

Willis, K.J., Bennett, K.D., 1994. The Neolithic transition-fact or fiction? Palaeoecological evidence from the Balkans. The Holocene, 4, 326-330.

Whitlock, C., Larsen, C., 2001. Charcoal as a fire proxy. In: Tracking environmental change using lake sediments (pp. 75-97). Springer Netherlands.

Yannouli, E., 1997. Dimitra, a Neolithic and Late Bronze Age village in Northern Greece: the faunal remains, in Grammenos D. Macédoine néolithique. Athènes, bureau archéologique, 101-127.

Zohary, D., 1996. The mode of domestication of the founder crops of Southwest Asian agriculture. The origins and spread of agriculture and pastoralism in Eurasia, 142-158. 


\begin{tabular}{|ccccc|}
\hline $\begin{array}{c}\text { Field sample code } \\
\text { (real depth) }\end{array}$ & Material & $\begin{array}{c}\text { Laboratory } \\
\text { sample Code }\end{array}$ & Age BP & Age Cal BC (2 $\sigma)$ \\
\hline Dik4 39-41 cm & Organic sediment & Poz-61976 & $2440 \pm 30$ & $751-408$ \\
Dik4 60-61 cm & Organic sediment & Lyon-10800 & $3110 \pm 30$ & $1437-1288$ \\
Dik4 72,5cm & Organic sediment & Beta-273956 & $4310 \pm 40$ & $3020-2880$ \\
Dik4 88-89 cm & Organic sediment & Lyon-10801 & $5205 \pm 45$ & $4288-3947$ \\
Dik4 96-97 cm & Organic sediment & Erl- 15214 & $6485 \pm 34$ & $5511-5370$ \\
Dik4 101-102 cm & Organic sediment & Lyon-10799 & $6575 \pm 35$ & $5613-5478$ \\
Dik4 118-119 cm & Organic sediment & Poz-61977 & $8540 \pm 35$ & $7598-7537$ \\
Dik4 146-147 cm & Organic sediment & Lyon-10803 & $9475 \pm 40$ & $9117-8635$ \\
Dik4 164-165 cm & Organic sediment & Poz-65263 & $11380 \pm 50$ & $11369-11153$ \\
Dik4 178-179 cm & Organic sediment & Poz-65264 & $11780 \pm 60$ & $11792-11523$ \\
\hline
\end{tabular}

Fig1. Location

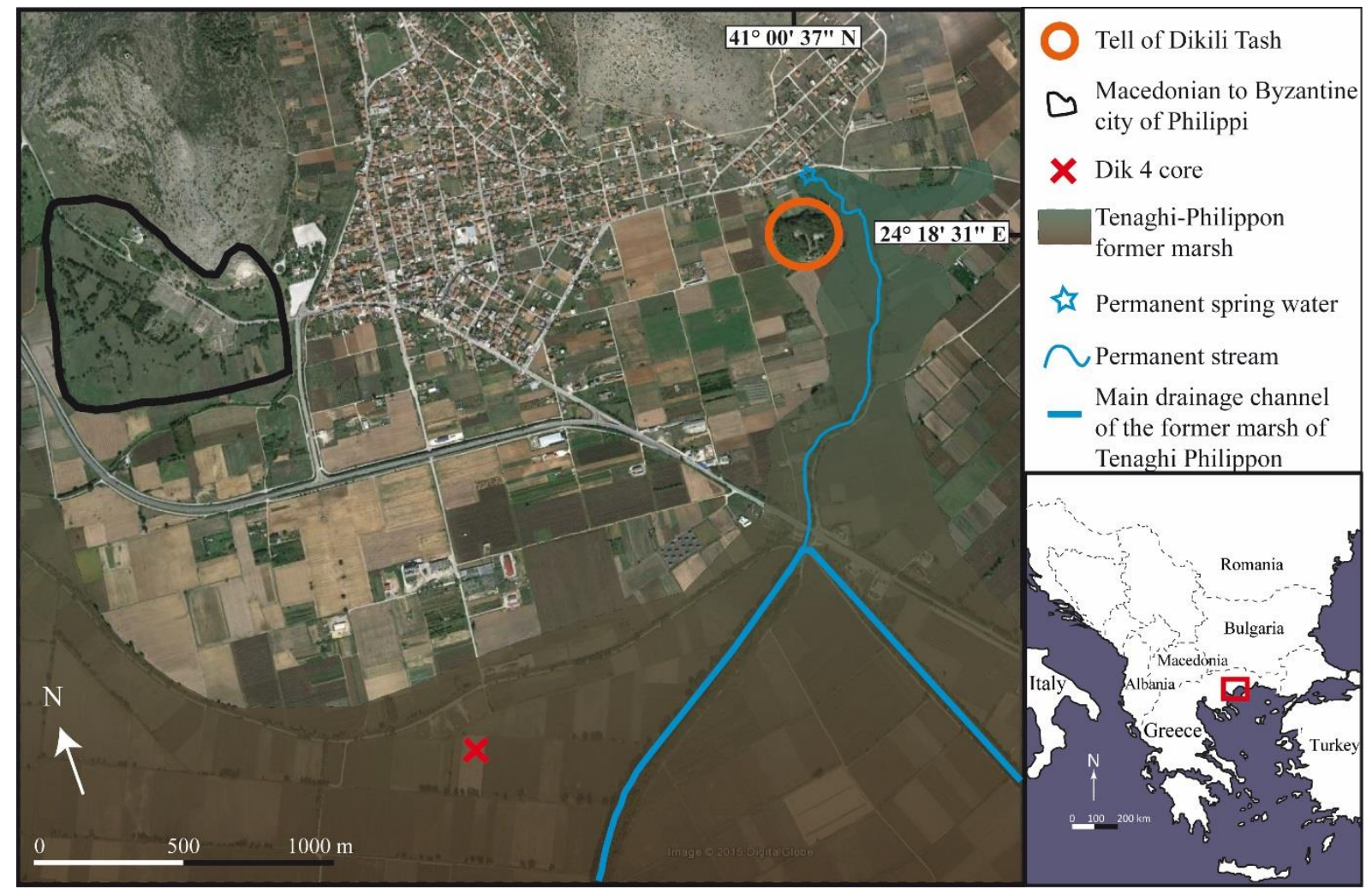


Fig2. Archaelogical context

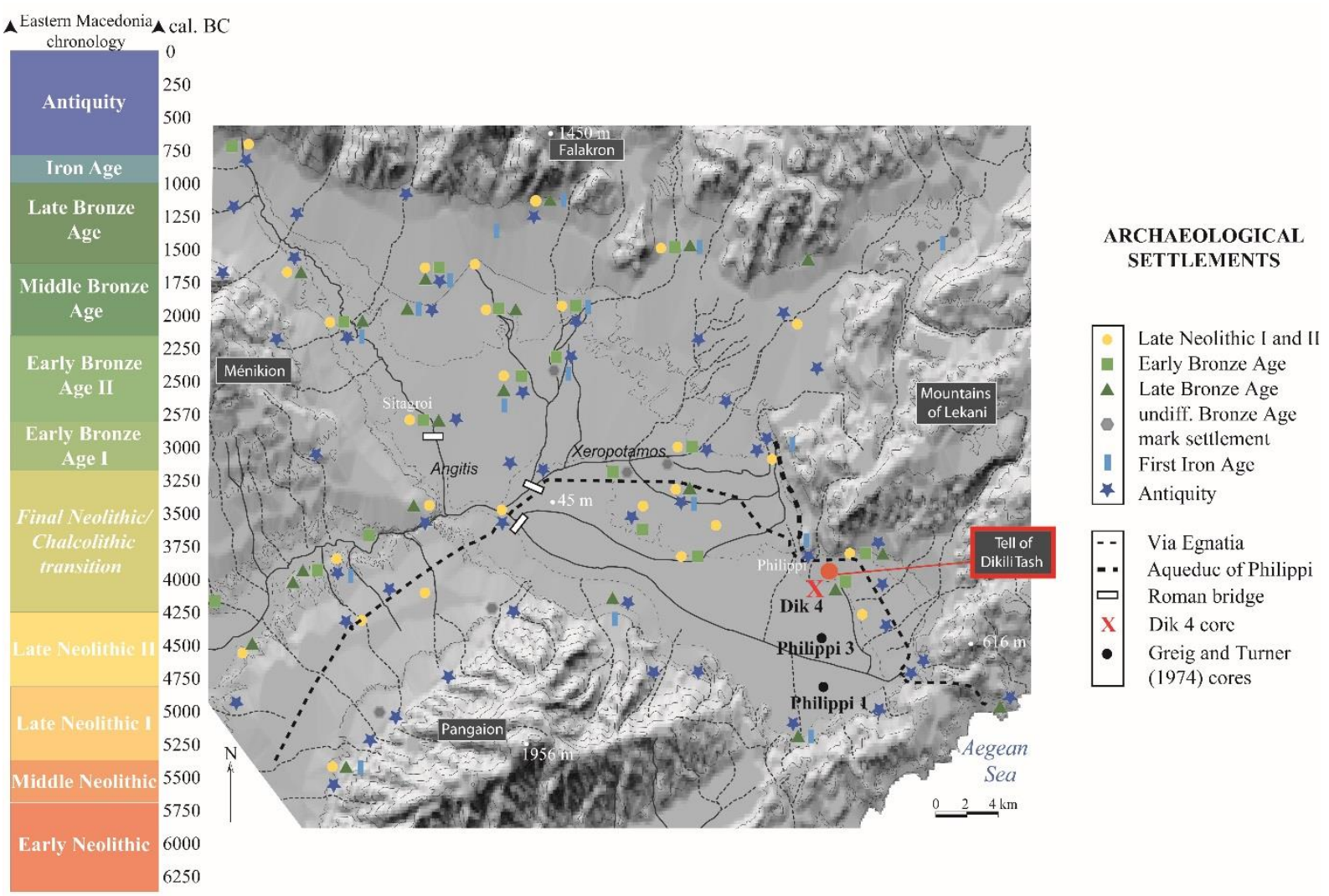

Fig3. Age-Model Dik4

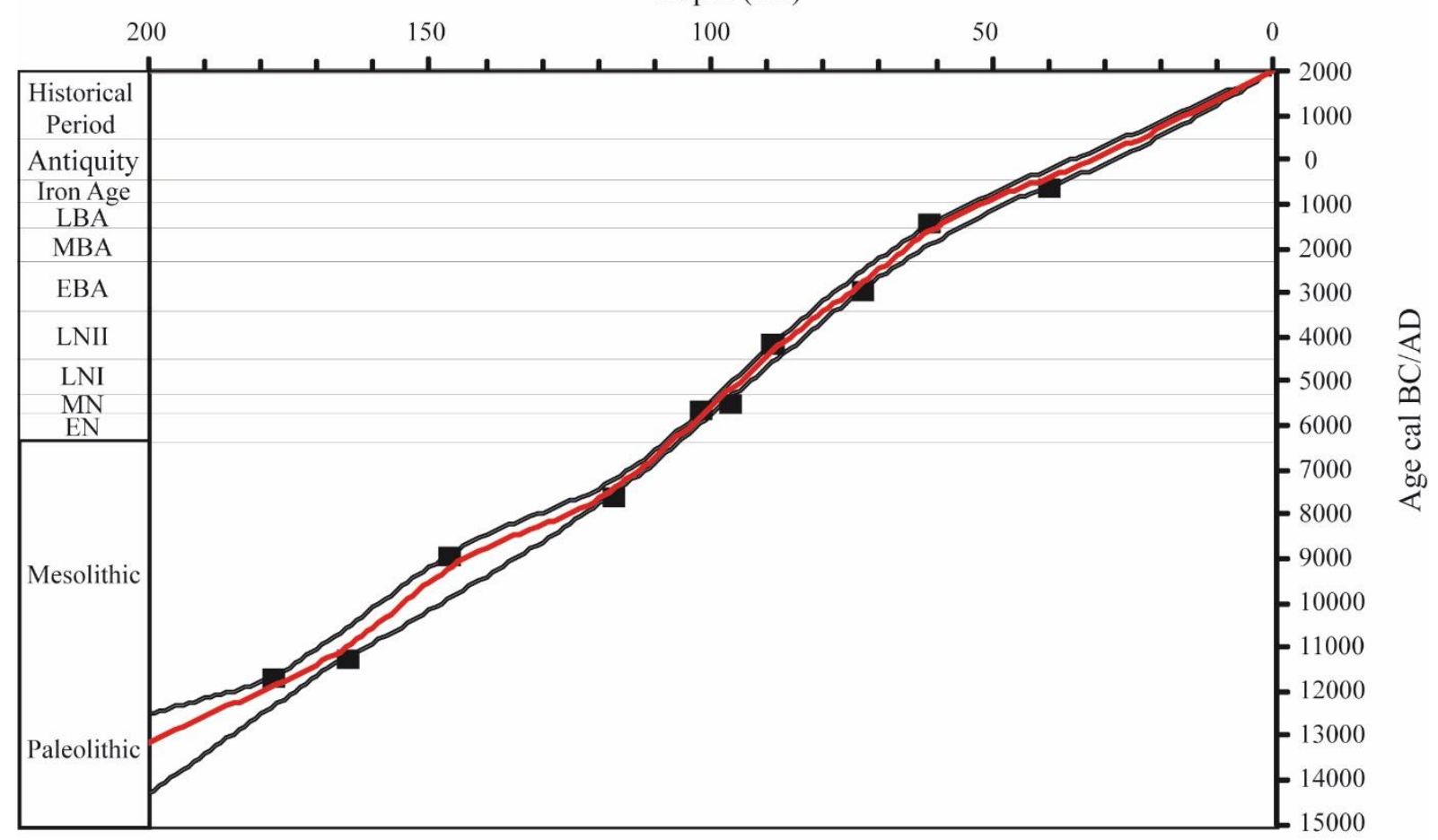


Fig4. Log loi caco3

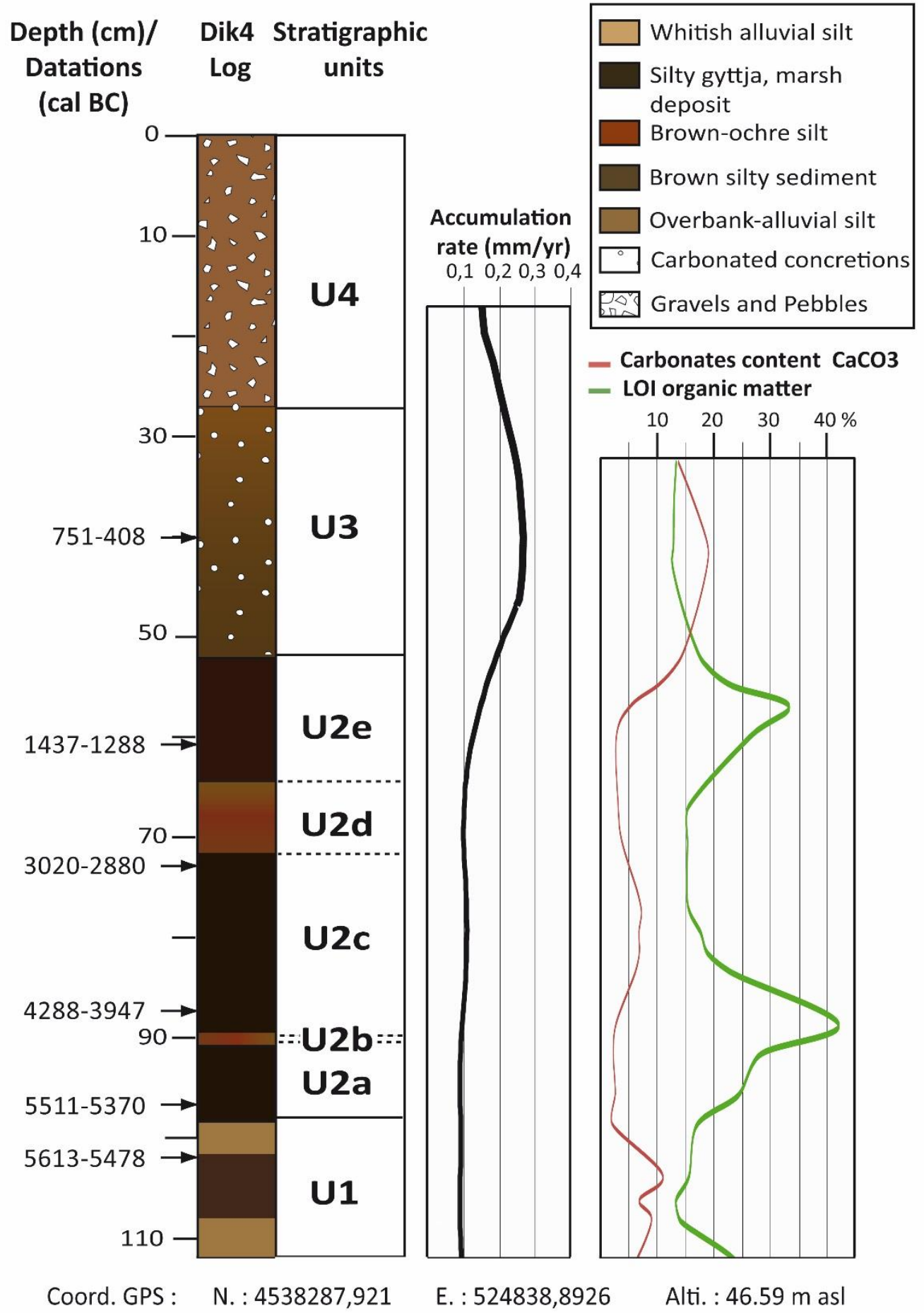


Fig5. Dik4_Charcoals

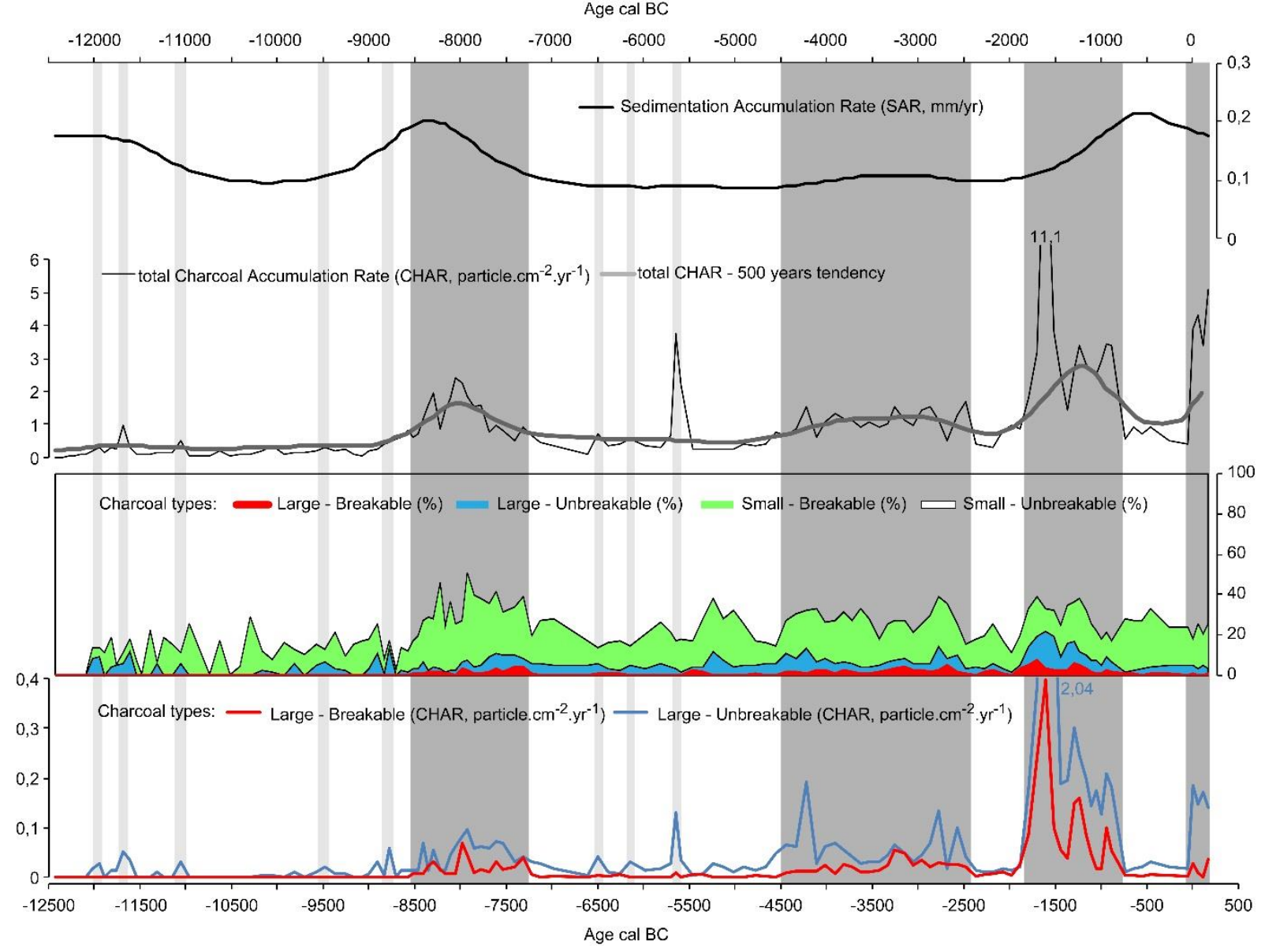

Fig6. Diag Dik4 Trees Shrubs

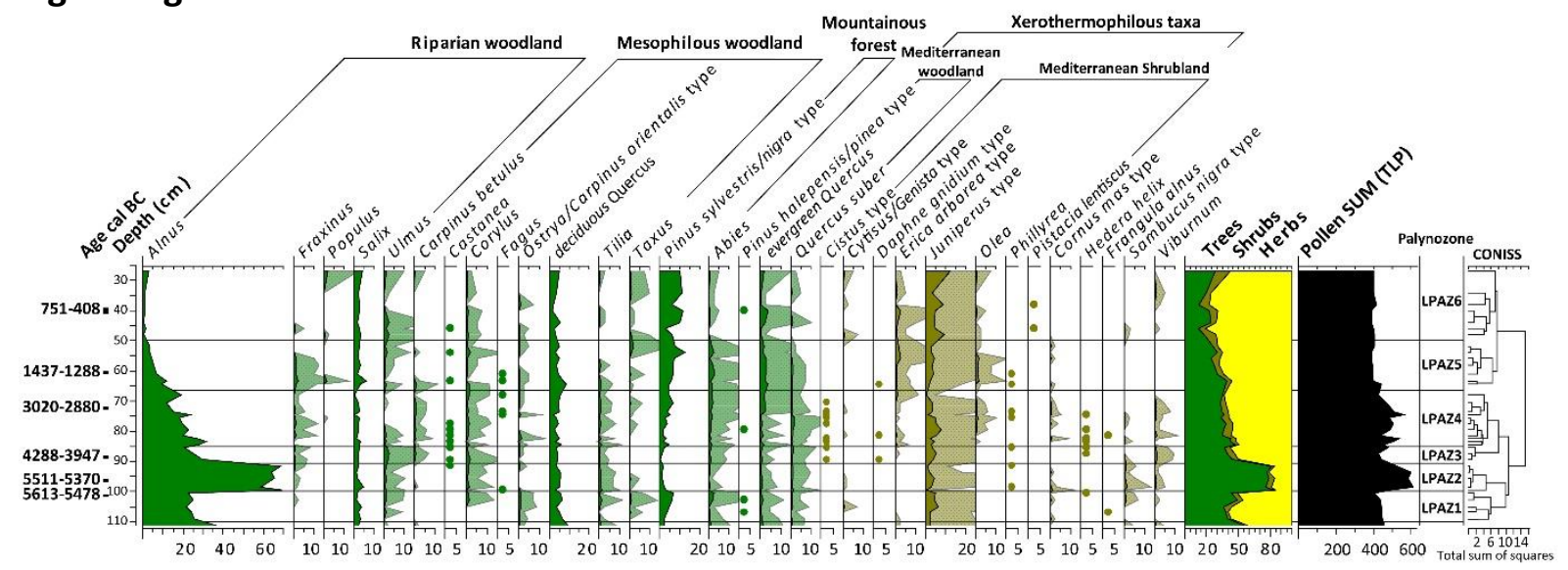


Fig7. Diag Dik4 herbs

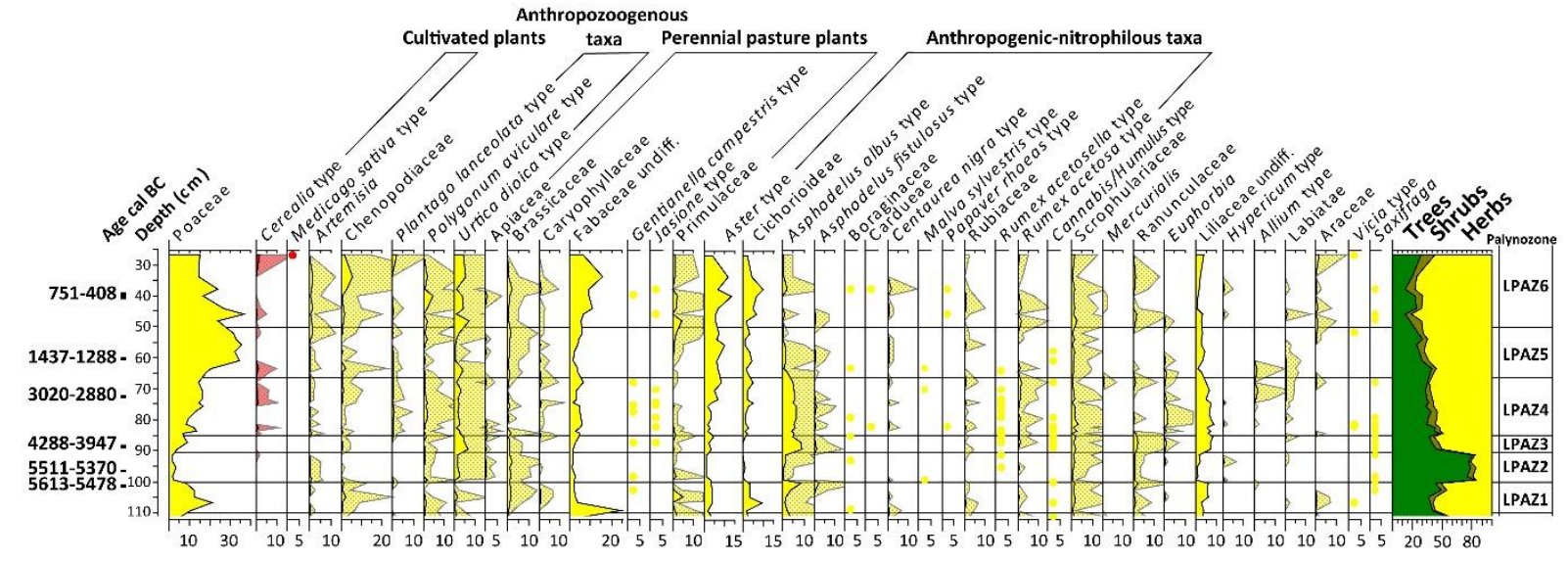

Fig8. Diag Dik4 NPPs and Hydr

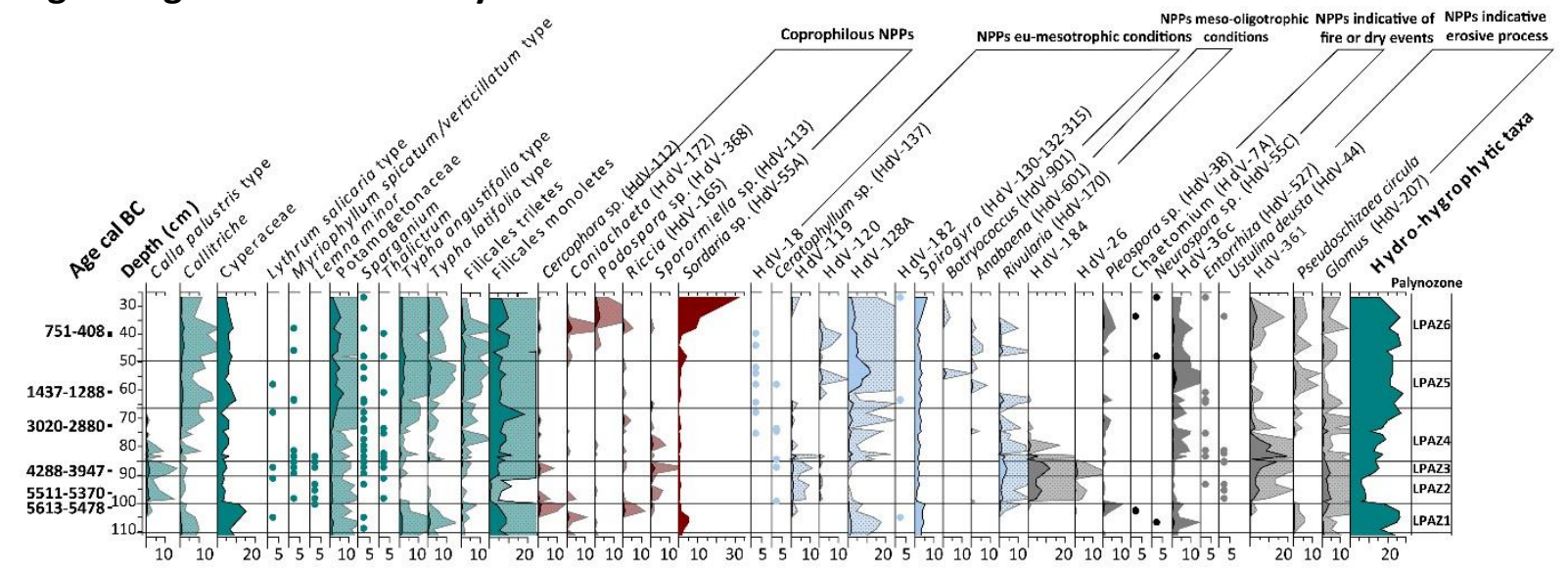

Fig9. diag Dik4 synthetic

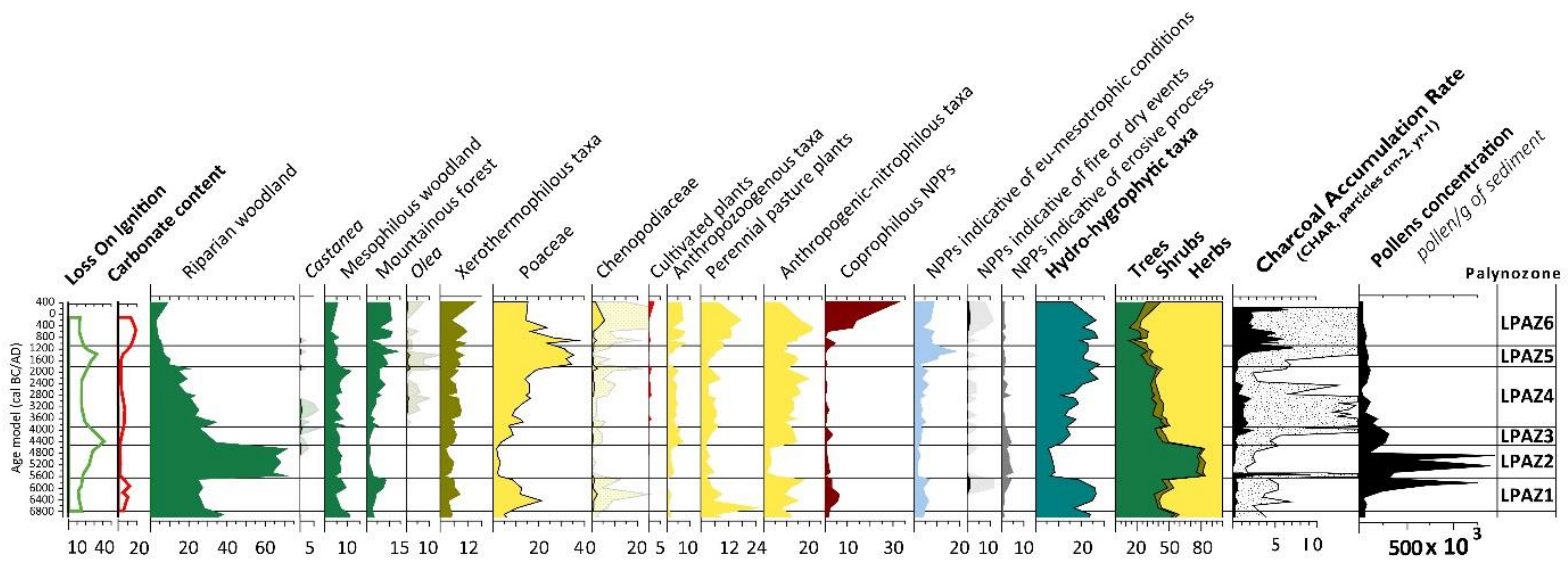

